\title{
THE DISTRIBUTION AND CONTAMINANT EXPOSURE OF RAFINESQUE'S BIG-EARED BATS IN SOUTH CAROLINA WITH AN EMPHASIS ON BRIDGE SURVEYS
}

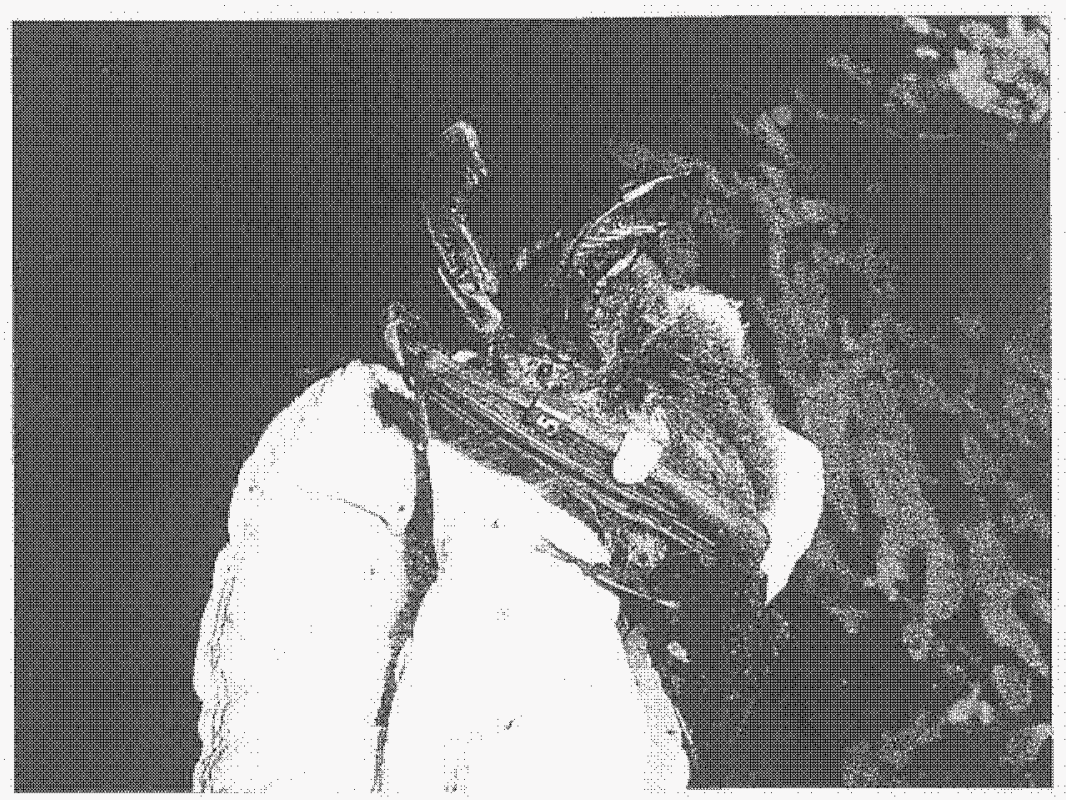

Frances M. Bennett ${ }^{1}$, Susan C. Loeb ${ }^{2}$ and William W. Bowerman ${ }^{1}$

Department of Forestry and Natural Resources Institute of Envirommental Toxicology

Clemson University

P. 0. Box 709

Pendleton, South Carolina 29670

${ }^{2}$ United States Forest Service

Southern Research Station.

Clemson, South Carolina 29634

Final Report to

South Carolina Department of Natural Resources

United States Forest Service

and

United States Fish and Wildife Service

October 23,2003 


\section{Introduction}

\subsection{Background and Conservation Status}

Rafinesque's big-eared bat (Corynorhinus rafinesquii), an insectivorous mammal indigenous to the southern United States, has long been referred to as one of the least known bats in North America (Barbour and Davis 1969). Although there has been a moderate increase in the number of peer-reviewed articles (Hurst and Lacki 1999, Lance et al. 2001, Menzel et al. 2001) published on this species in the past 6 years, the basic ecology and status of Rafinesque's big-eared bat remains largely obscure. Prior to 1996 , when the United States Fish and Wildlife Service (USFWS) discontinued the list of Candidate Species (USFWS 1996a, 1996b), Rafinesque's big-eared bat was listed as a Federal Category 2 Candidate species (USFWS 1989). Currently, Rafinesque's big-eared bat is recognized as a "species of special concern" across most of its range (Table 1) but receives no legal protection. Nonetheless, the USFWS and numerous state agencies "remain concerned about this species, but further biological research and field study are needed to resolve the conservation status of this taxon(a)" (USFWS 1996a).

In South Carolina, Rafinesque's big-eared bat is listed as State Endangered (SC DNR 2001, Table 1). Anecdotal evidence suggests Rafinesque's big-eared bat has decreased significantly over the past 25 years in South Carolina and continues to experience declines (M. Bunch, person. commun.) but due to difficulties in locating and monitoring this species, there are no reliable data to support such conclusions. Museum and incidental capture records of Rafinesque's big-eared bats in South Carolina have recently been summarized (Menzel et al. 2003) but to date, there have been no thorough field-based surveys on the distribution of Rafinesque's big-eared bat in South Carolina. 


\subsection{Causes of Potential Population Declines}

The main threats to this bat are not well understood; likely impacts include habitat loss, disturbance and destruction of roosting sites, isolation effects due to limited dispersal by females, and exposure to anthropogenic compounds (Clark 1990, Lacki 2000, Lance and Leberg 1999, Hickey et al. 2001). Habitat loss in coastal areas, particularly of mature bottomland forests containing old-growth gum ( $N y s s a$ sp.) trees, has likely had a negative impact on populations of big-eared bats (Clark 1990). Trees with large cavities are used as natural roost sites by this species; however, they are also known to roost in abandoned buildings, wells, and under highway bridges (Clark 1990, Clark et al. 1998, Hoffman et al. 1998, Lance et al. 2001, Mirowsky 1998). Although these anthropogenic structures benefit big-eared bats by providing alternate roosting sites, they also may expose the bats to increased disturbance. Disturbance to big-eared bats can have a number of negative effects, particularly for maternal groups (Bagley 1984, Lacki 2000). If aggravated, big-eared bats may abandon theit pups or roosts, and can experience an increase in energy expenditures as their colony size decreases (Bagley 1984, Lacki 2000, McCracken 1989).

The tendency for Rafinesque's big-eared bat to utilize highway bridges for roosting sites may be useful in their conservation. Rafinesque's big-eared bats are known to use bridges as roosts in other southern states (McDonnell 2001; Lance et al. 2001; Trousdale and Beckett 2002; Gore and Hovis 1997). However, in South Carolina the frequency of bridge use is not known. In Texas, Rafinesque's big-eared bats use artificial structures as primary roosts and natural structures as alternate roosts (Mirowsky, 1998). Thus, it is likely that a significant proportion of the population in South Carolina utilizes 
bridges where available. Highways and bridges are abundant in South Carolina and are more permanent than abandoned buildings and large hollow trees. Therefore, bridges that are present within the bat's range may offer a viable solution to easing the shortage of roost sites in South Carolina.

Another important factor in the potential decline of Rafinesque's big-eared bat is that of environmental pollution. Evidence is increasing that exposure to environmental contaminants, especially in industrialized areas, is a significant cause in the global decline of bat populations (Gerell and Lundberg 1993, Clark 2001, Hickey et al. 2001). Chemical residues indicative of contaminant exposure can be detected and quantified in tissues of wildlife, including bats (Clark et al. 1978, Clark et al. 1995, Grippo and Massa 2000, Hickey et al. 2001, O'Shea et al. 2001, Fernandez et al 1993). If present at sufficient levels in an organism, toxicants can ultimately cause decreased reproduction and growth rates, altered behavior (such as reduced attentiveness to offspring) and even mortality (Clark et al. 1978, Shore et al. 1991). Organochlorine pesticides have been identified as a causal agent in the decline of millions of Brazilian free-tailed bats (Tadarida brasiliensis) in New Mexico (Clark 2001), and in the mortality of endangered gray bats (Myotis griscens) in Missouri (Clark et al. 1978). In addition, many environmental contaminants are known to be teratogenic, carcinogenic, neurotoxic, and genotoxic (Hoffman et al. 2001). It is clear that anthropogenic compounds are impacting bat populations on a large scale, however the effects of contaminants on Rafinesque's big-eared bat have not been evaluated. 


\subsection{Objectives}

In response to the paucity of information regarding the status and distribution of Rafinesque's big-eared bat in South Carolina, we initiated a state wide survey of this species. In addition, to address potential impacts of environmental contaminants on this bat, an evaluation of the heavy metals affecting Rafinesque's big-eared bats was conducted. In summary, the main objectives of this study were:

I. Determine the distribution and numbers of Rafinesque's big-eared bat in South Carolina using highway bridges as roost sites.

II. Begin long-term monitoring of Rafinesque's big-eared bats in South Carolina by capturing and tagging individuals in different colonies.

III. Evaluate the exposure of Rafinesque's big-eared bat to heavy metals using hair samples.

\section{Materials and Methods}

\subsection{Study Area}

South Carolina is divided into four physiographic provinces: Blue Ridge, Piedmont, Upper Coastal Plain, and Lower Coastal Plain (Fig.1). Each province has a distinct climate, location, topography, and geology, which, along with historic and current land use practices, can have a major influence on the structure and composition of floral and faunal communities (Menzel et al. 2003). The Blue Ridge region, a part of the southern Appalachian Mountains, is situated in the upper northwestern portion of South Carolina. It is the smailest geographical region $\left(1,554 \mathrm{~km}^{2}\right)$ in the state, has a mountainous topography and ranges in elevation from 427 to $1,067 \mathrm{~m}$. The central Piedmont area covers the northwestern portion $\left(25,749 \mathrm{~km}^{2}\right)$ of the state. It has a rolling topography and ranges in elevation from 91 to $366 \mathrm{~m}$. Together, the Upper and Lower 
Coastal Plain provinces cover the largest area of South Carolina $\left(51,800 \mathrm{~km}^{2}\right)$, extending 193 to $241 \mathrm{~km}$ inland from the Atlantic Ocean. The highest elevation in the Coastal Plain provinces is $91 \mathrm{~m}$.

The climate of South Carolina is warm temperate to subtropical, with annual average temperatures ranging from $12^{\circ} \mathrm{C}$ in the Blue Ridge up to $17^{\circ} \mathrm{C}$ in the Coastal Plain. Summers are long, with peak annual precipitation occurring in July; while winters are short and mild. Annual precipitation can be as much as $200 \mathrm{~cm}$ in the Blue Ridge, but averages $130 \mathrm{~cm}$ in the Coastal Plain and Piedmont (South Carolina State Climatology Office, 2003).

\subsection{State-wide Bridge Surveys 2002}

From 22 May 2002 to 8 August 2002, a county-by-county survey for Rafinesque's big-eared bats utilizing highway bridges as day roosts was initiated in South Carolina. Bridge data including structure type, construction material, location, identification number, and bridge length were obtained from the South Carolina Department of Transportation (Lee Floyd, SCDOT) and used to direct the survey effort. For each of the 46 counties in South Carolina, bridges were grouped according to structure type, the variable found to have the most influence on selection by big-eared bats (Lance et al. 2001). The three main types of bridges in the state are known as slab, multi-beam, and T-beam. Slabs are structurally simple, flat-bottomed bridges usually made of concrete (Fig. 2). There is little shelter under these bridges for roosting bats. Multi-beam bridges have a variable construction but generally consist of parallel beams that span the entire length of the bridge (Fig. 3). Multi-beam bridges are also known as Ibeam or channel beam bridges. The size of the support beams, as well as the space 
between them is variable. The area between beams can offer shelter to roosting bats. Multi-beam bridges are often constructed with a combination of steel and concrete, but can also be made with timber. Like multi-beams, T-beam bridges have parallel beams that span the entire length of the bridge; but in addition, the support beams are intersected at right angles by cross beams (Fig. 4). This intersection forms a $T$-shaped junction, and also provides shelter for bats to roost in. In South Carolina, these bridges were constructed solely of concrete. Rafinesque's big-eared bat is known to roost in close proximity (within 1-2 km) of permanent water bodies (Clark, 1990), so only bridges over water were surveyed. Bridge types other than slabs, multi-beams and T-beams are constructed in South Carolina but are uncommon over water bodies.

In South Carolina, some bridge types were more common than others, and the relative numbers of each structure also varied by county. In generaI, slab bridges were by far the most abundant, followed by multi-beam and T-beam bridges. Initially, bridges were randomly sampled according to their proportion, resulting in more slab bridges being checked than either multi beam or T-beam bridges. However, this sampling approach was changed based on our initial findings as well as those of Lance et al. (2001) and McDonnell (2001), which indicated that Rafinesque's big-eared bats were not utilizing all structural types equally. Subsequently, to maximize our chances of locating bats, our survey was focused on the structural type that Rafinesque's big-eared bats were known to be using. For the remainder of the survey period we did not randomly select bridges but rather, focused our efforts on checking bridges in the following order of preference: T-beam, multi-beam, and slab. More T-beams in South Carolina were surveyed than multi-beams and slab bridges. 
While conducting the statewide survey, we found that many bridges were built using a combination of two structure types. For example, the ends of the bridge that intersected land could be structurally different than the middle section. The distinction in structure type between the ends and middle sections of a bridge is important because bats are usually found roosting in only the end sections. In these instances we recorded the bridge type as that which was found at the ends of the bridges. Each bridge was checked once during the 2002 season. For safety reasons, bridges on interstate highways were not included in this study. In addition, some bridges were inaccessible and were not included in the survey. Only public lands, (including National Forests) were included in this survey.

The undersides of bridges were checked using $1,000,000$ candle-powered flashlights for the presence of bats and their characteristic fecal pellets. Guano was used to indicate occupancy by Rafinesque's big-eared bat, and was also collected for contaminant analysis. For each bridge that was surveyed field personnel gathered the following information: date; county; latitude/longitude; numbers and species of bats present; surrounding habitat; and disturbance under the structure. If bats were found under a bridge, a detailed description of toost location and group type (maternity colony, solitary bat, or group of adult bats only) was also recorded. Juvenile big-eared bats can be visually identified based on their size and/or pelage color and texture, which is a downy, light-brown color. If pups were observed, the roost was identified as a maternity colony. Independent counts of pups and adults were made by at least 2 field personnel and compared to ensure the most accurate count of bats in the roost. In some instances, total 
counts were not taken to reduce the level of disturbance to the bats. In these cases an approximate range of the numbers of bats present was recorded. For statistical analysis, the least number of bats present was used. In addition, as the summer progressed, it was easier to observe pups as they grew; thus there is likely a temporal bias in the number of bats counted under bridges from May-August.

Because Rafinesque's big-eared bats are highly sensitive to disturbance (Lacki 2000), we attempted to quantify this factor for each bridge. The level of disturbance was rated on a discrete scale of $0-3$, with 0 being the lowest and 3 being the highest. Factors adding to increased disturbance included presence or evidence of humans such as trash, vandalism, footprints, ATV or other tracks and heavy traffic on the surface of the structure. Non-human disturbances were primarily associated with cattle and birds such as swallows (Tachycineta and Petrochelidon spp.) that nest in large noisy groups under bridges. It is not known whether a big-eared bat will abandon a bridge roost if birds or other non-predatory animals including domestic cattle simultaneously occupy it, but we observed Rafinesque's big-eared bats roosting under bridges where both birds and cattle were found.

The fecal pellets of Rafinesque's big-eared bat can be distinguished from other species due to a characteristically slender, somewhat helical shape (Hurst \& Lacki 1997). If guano was present it was collected and stored at room temperature in hexane-rinsed foil and then wrapped in a plastic sample bag and labeled with the collector's name, date, bridge number, unique guano identification number and contents. Upon arrival at Clemson University, all guano samples were stored at $-20^{\circ} \mathrm{C}$ until laboratory analysis. Fecal pellets were most often collected as individual pieces from the cement walls of the 
bridges; occasionally they were present in large enough quantities to be collected from the ground. If the guano was from an unknown bat species it was collected and recorded as such. Guano samples were ranked according to the level of certainty that it was from a big-eared bat. For example if guano was collected from the same bridge where Rafinesque's big-eared bats were observed, it was assumed to have originated from those bats. Residue analysis using big-eared bat guano is currently in progress and the results are thus not reported here.

\subsection{Bridge Survey 2003}

Bridge surveys were conducted from 23 May 2003 to 1 August 2003 using similar methods to those used in 2002. The undersides of bridges were again checked for bats and guano using $1,000,000$ candle-powered flashlights and the same data were collected as in 2002 (date, county, latitude/longitude, numbers and species of bats present, surrounding habitat, and disturbance under the structure).

Although the 2003 field survey was similar in execution to the 2002 statewide survey, there were two important differences. First, we did not survey the entire state. Instead surveys were focused on those bridges where either big-eared bats or their guano were identified in 2002 . We also checked additional bridges ( $\mathrm{T}$-beam and multi-beam) that may be suitable roost sites but were not checked in 2002 . We attempted to monitor these sites throughout the summer instead of checking the structure only once. Most bridges with bats were checked every 2-3 weeks. Second, in addition to counting Rafinesque's big-eared bats under bridges, we tagged bats to identify individuals and collected hair samples for contaminant analysis. 


\subsection{Capture and Tagging}

Methods used to capture bats depend on the type of roost, the number of bats present, their alertness, age, reproductive condition and accessibility to researchers (Kunz and Kurta 1988). Bats are commonly caught while in flight using mist nets; however the same method was inappropriate for capturing roosting bats in small, enclosed spaces such as underneath a bridge. Instead we used two capture devices: 1) hand-held mist nets, also known as $\mathrm{H}$-nets (Waldien and Hayes 1999) to capture bats under bridges; and 2) hoop nets, also known as insect nets. Briefly, H-nets were constructed using a frame of 1.27 $\mathrm{cm}$ diameter PVC pipe and a mist net cut to size, held in place with electrical tape. Once assembled, the nets were approximately $160 \mathrm{~cm} \times 90 \mathrm{~cm}$, and were compact enough to be used in tight spots under bridges. Hoop nets consisted of a bag made of mosquito netting with a depth of approximately $40 \mathrm{~cm}$ and a diameter of $45 \mathrm{~cm}$, and an adjustable length plastic handle.

Choice of capture device depended on the location of bats under the bridge. The ends of the bridge, (where the structure intersects the land) can act as a trap for bats if they are roosting in this area. If bats were roosting on a beam near the end of the bridge or if we could flush the bats into this enclosed beam area, H-nets were used. Some interbeam spaces were wide enough to allow $2 \mathrm{H}$-nets to be used simultaneously. In these instances, bats were corralled towards the end of the abutnent where there is a concrete wall. We attempted to pin the bat between the net and the wall and then remove each bat from the net by hand. Hoop nets were used if the bats were roosting in a tight cluster, away from the ends of the bridge. Without disturbing the bats and causing them to 
disperse, we used the hoop net to catch bats against the cement and become entangled in the bag of the net. If necessary, we also adjusted the handle length.

Of particular concern when capturing Rafinesque's big-eared bats is their potential to abandon their roosts and/or pups if their roost sites are disturbed too much (Lacki 2000). Consequently, we did not begin banding activities until pups were volant and less dependent on their mothers while roosting. Rafinesque's big-eared bat pups are usually volant 3-4 weeks after parturition (which occurs in late May; Jones and Suttkus 1975 , Clark 1990). In the present study, we did not attempt to capture big-eared bats until pups could be readily observed roosting on their own. In addition, we only captured bats from a roost once during the summer to minimize disturbance.

Banding activities for Rafinesque's big-eared bats were initiated on 30 June 2003 and completed on 1 August 2003. Upon locating a roost, the number and dispersal of bats was noted quickly to reduce disturbance (and thus dispersal) in the colony. Precautions were taken to reduce the handling time of each bat, and if more than one was caught at a roost they were released together at the capture site. All processing was done on site (under the bridge) without exposing the bats to direct sunlight. All bats were banded with a $2.9 \mathrm{~mm}$, aluminum alloy lipped-wing band (Lambournes B'ham Ltd, UK) and a color plastic split ring band (A.C. Hughes Ltd, Middlesex, UK). Females were banded on their left forearm, males on the right. Each aluminum band had a unique number and the United States Forest Service (USFS) initials on it. Four different colored plastic bands were used: orange, red, pink and white; each numbered from 1-20. Bats in the same area were banded with the same color. Each bat was sexed and if possible, their reproductive condition was also determined according to Racey (1988). Age was determined as either 
adult ( $>1$ year old) or juvenile ( $<1$ year old) by looking at the degree of ossification in the epiphyseal-diaphyseal joint (Anthony 1988). If either age or sex could not be positively identified, they were recorded as unknown. A hair clipping was taken from the dorsal region of each bat using fine-pointed scissors. Two wing punches were taken from each bat using $3 \mathrm{~mm}$ sterile biopsy punch. All samples taken were stored in separate vials with a unique identifying number.

\subsection{Metal Analysis in Rafinesque's Bigreared bat Hair}

All hair collected during the 2003 banding activities was analyzed for trace elements. Total aluminum ( $\mathrm{Al}$ ), arsenic (As), cadmium (Cd), chromium (Ct), copper $(\mathrm{Cu})$, mercury $(\mathrm{Hg})$, nickel $(\mathrm{Ni})$, lead $(\mathrm{Pb})$, selenium $(\mathrm{Se})$, and zinc $(\mathrm{Zn})$ were measured using the Elan Sciex 9000 inductively coupled plasma - mass spectrophotometer. Protocol for analysis was done using United States Environmental Protection Agency's Method 200.8. Prior to analysis, all hair samples were prepared in a microwave-assisted digestion in a 30\% nitric acid solution. Samples were run in triplicate. The detection limits $(\mu \mathrm{g} / \mathrm{L})$ for each metal were: $\mathrm{Al}, 5.338 ; \mathrm{As}, 0.046 ; \mathrm{Cd}, 0.006 ; \mathrm{Cr}, 0.062 ; \mathrm{Cu}, 0.162$; $\mathrm{Hg}, 0.008 ; \mathrm{Ni}, 0.129 ; \mathrm{Pb}, 0.056 ; \mathrm{Se} .0 .207 ; \mathrm{Zn}, 1.864$. Results are reported in $\mu \mathrm{g} / \mathrm{g}$.

\subsection{Statistical Analyses}

All statistical methods were done using SAS software (version 8.02). The rejection level was set at alpha $=0.05$. For the 2002 and 2003 bridge surveys, occupied and unoccupied bridges were compared statistically between bridge type and physiographic region using the Tukey-Kramer method for multiple comparisons (PROC ANOVA procedure). Occupancy of bridges according to length was only compared for the 2002 data set using the Tukey-Kramer method. For length, bridges were categorized 
for statistical analysis. The categories for bridge length were: $20-39 \mathrm{~m} ; 40-59 \mathrm{~m} ; 60-79$ $\mathrm{m} ; 80-99 \mathrm{~m} ; 100-199 \mathrm{~m} ; 200-399 \mathrm{~m} ;$ and $400-1600 \mathrm{~m}$.

Because of small sample sizes, data that were collected from banding activities as well as the results of the metal analysis were analyzed using the Kruskall-Wallis nonparametric one-way analysis of variance (NPAR1WAY procedure). Weight and forearm length were compared among age and sex classes. Forearm length was categorized into four groups for statistical analysis. The groups were: $40.5-41.5 \mathrm{~mm}$; 41.6 - 42.5 mm; 42.6- 43.5 mm; 43.6- 45.2 mm. Also, weight and forearm length were compared for statistical significance. For the metals, total $\mathrm{Al}, \mathrm{Cd}, \mathrm{Cr}, \mathrm{Cu}, \mathrm{Hg}, \mathrm{Ni}, \mathrm{Pb}, \mathrm{Se}$, and $\mathrm{Zn}$ were compared statistically between age and sex class, and location. Hair samples below detection limits were not included in the analyses. All data are reported as geometric means and standard deviations of the mean.

\section{Results}

\section{I State-wide Bridge Survey 2002}

From 22 May 2002 to 8 August 2002, 1129 bridges were surveyed for the presence of Rafinesque's big-eared bats and their guano in South Carolina. Guano was used to indicate occupancy by big-eared bats. A summary of bridge types (slab, multibeam and T-beam) that were surveyed in each of the state's forty-six counties is shown in Table 2. Overall, we checked $5.50 \%$ of slab bridges, $20.68 \%$ of multi-beam bridges and $89.69 \%$ of T-beam bridges that span permanent water bodies in South Carolina (Fig. 5). Figure 6 shows the distribution of occupied bridges in the initial sampling period (bridges were sampled in proportion to their abundance; top graph), and the subsequent weighted sampling period (bridges were not checked in proportion to their abundance; bottom 
graph). The distribution of occupied bridges was the same in each sampling period (P> $0.05)$ and there was a significant relationship between structure type and occupancy when data from both periods were combined $(\mathrm{P}<0.001$; Fig. 7). Big-eared bats were found underneath 37 bridges in South Carolina; their guano was found underneath 115 bridges. A map of the distribution of occupied bridges is shown as Figure 8. Of the 37 occupied bridges, 31 were T-beams and the remaining 6 were multi-beams. Both maternal $(n=16)$ and solitary ( $\mathrm{n}=51$ ) roosts were found underneath 13 and 33 highway bridges, respectively. Often, more than one roost or roost type was found underneath the same bridge. In addition to recording the presence of Rafinesque's big-eared bats, their guano was collected from $101 \mathrm{~T}$-beam and 14 multi-beam bridges (Table 3 ). There were no bats or guano found underneath slab bridges in South Carolina.

Big-eared bats were primarily found roosting over the dry banks on either end of a bridge near its abutments; occasionally a solitary bat was found roosting in the middle section of a bridge if the waterbed was dry. Rafinesque's big-eared bats roosted in the moderately open sections between support beams; bats were never found roosting in the small expansion joints of a bridge. The number of bats found underneath a bridge ranged from $1-53$, with maternal roosts ranging in size from $3-53$ and averaging 11.98 bats (Fig. 9). These numbers are conservative as it was often difficult to get an exact count on a group of bats. Other bat species were also found roosting under highway bridges ( $\mathrm{n}=43$ ) in South Carolina representing the majority of observations (53.75\%). The majority of these bats were Pipistrellus subflavus, Eptesicus fuscus, Myotis austroriparius, and an unknown Myotis. Solitary roosting big-eared bats shared three bridges with other species, but were roosting in separate areas of the bridge. 
In addition to structure type other factors including physiographic region, disturbance, and bridge length were found to influence the selection of bridges by Rafinesque's big-eared bat. This species was only found roosting under bridges in the Upper and Lower Coastal Plain regions of the state $(\mathrm{P}<0.001$; Table 3). However there was no significant relationship between the distributions of bats in either Coastal Plain ( $\mathrm{P}$ $<0.4707)$ region. Rafinesque's big-eared bat was observed roosting under bridges with disturbance levels ranging from none to high (Fig. 10). However, the majority of roosts were underneath bridges with a disturbance rating of 1 or 2 , indicating an association between disturbance and roosting $(\mathrm{P}<0.001)$. Lastly, bridge length $(\mathrm{P}<0.0036)$ was significantly related to selection of bridges by Rafinesque's big-eared bats. The majority of bats were found under bridges $100-200 \mathrm{~m}$ long.

It is unclear whether a structure's material is an important factor in the selection of a bridge. Because all of the T-beams we surveyed were made of concrete, it was not possible to separate the influence of material on roost selection from structural type in this survey.

\subsection{Bridge Survey 2003}

From 23 May 2003 to 2 August 2003, highway bridges in the Upper and Lower Coastal Plain of South Carolina were monitored for the presence of Rafinesque's bigeared bats. A summary of the occupied bridges in 2003 can be found in Table 4 . Overall, 227 bridges were checked 460 times for the presence of Rafinesque's big-eared bats and their characteristic guano. A total of 52 bridges were occupied by Rafinesque's big-eared bats. Both maternal $(n=23)$ and solitary $(n=59)$ roosts were identified under 24 and 46 bridges respectively. As in 2002, more than one roost or roost type was often found 
underneath the same bridge (Table 4). Bridges with bats were checked an average of 3.07 times, with a minimum of 1 and a maximum of 5 times during the 2003 survey period. As in 2002, Rafinesque's big-eared bats were primarily found under T-beam bridges ( $\mathrm{n}=$ 49 ); the remaining occupied bridges $(n=3)$ were multi-beams. Nineteen bridges had bats in both 2002 and 2003; 15 bridges with bats in 2002 did not have bats in 2003. Bats were found under an additional 32 bridges in 2003 . Of these 32 bridges, 6 had not been previously checked in 2002 for bats. Because of time constraints, 5 bridges with solitary bats in 2002 were not checked in the 2003 survey.

In the 2003 monitoring survey an additional type of Rafinesque's big-eared bat roost was identified. This roost type consisted of 2 or 3 bats roosting together, and they appeared to be adults without pups. We identified 8 of these roosts, which consisted of a total of 18 bats.

\subsection{Capture and Tagging}

From 30 June 2003 to 1 August 2003, 60 Rafinesque's big-eared bats were captured from highway bridges in South Carolina and tagged for identification. Bats were captured from 25 bridges within the Upper and Lower Coastal Plain provinces. Numbers of bats tagged at each bridge ranged from 1-9. The sex and age composition of tagged bats are shown in Figure 11.

Because our objective was not to monitor the use of bridges by individual bats, we did not often return to a bridge once bats had been banded. This was done to reduce the chance that the bats may abandon the roost. Long term monitoring of Rafinesque's big-eared bats under bridges will likely be done in the future. However, we did revisit several bridges and recaptured a single bat from the same bridge where it had been 
initially banded. The bat was a lactating female (USFS band \#427) from a maternai roost of 15 other bats. Two days after being initially captured, this bat appeared healthy; the bands were not irritating her membrane, and her weight was stable at approximately 8.0 g. In addition, the same numbers of bats $(n=16)$ were present in the roost. Another bat from this roost that had been banded on the first visit, an adult female, was resighted during the second visit. The plastic split ring band was no longer attached to the forearm, but the aluminum alloy USFS band was easily visible as the bat roosted among its group. Another bat, USFS band \#405, which was originally banded on 1 July 2003 , was recaptured 29 days later. This bat was an adult male and was recaptured at a different bridge less than one $\mathrm{km}$ from the original bridge. Both bands were still intact on the bat's forearm and did not appear to be causing it any distress. Of particular note is the increase in weight this bat showed over the period of 29 days. When originally captured, it weighed $7.50 \mathrm{~g}$; when recaptured its weight had increased by approximately $2.0 \mathrm{~g}$ and was $9.5 \mathrm{~g}$.

Body weight was significantly related to age and sex. Adult females were the heaviest group $(\mathrm{n}=25 ; x=8.98 \mathrm{~g} \pm 1.18 \mathrm{~g} ; \min 6.00 \mathrm{~g} ; \max 10.25 \mathrm{~g})$ followed by juvenile females $(\mathrm{n}=3 ; x=8.67 \mathrm{~g} \pm 0.88 \mathrm{~g} ; \min 7.75 \mathrm{~g} ; \max 9.5 \mathrm{~g})$, adult males $(\mathrm{n}=16$; $x=7.69 \mathrm{~g} \pm 1.15 \mathrm{~g} ; \min 5.3 \mathrm{~g} ; \max 9.30 \mathrm{~g})$ and finally juvenile males $(\mathrm{n}=15 ; x=7.59 \mathrm{~g}$ $\pm 0.84 \mathrm{~g} ; \min 5.63 \mathrm{~g} ; \max 9.0 \mathrm{~g})$. In addition, there was an association between sex and length of the forearm $(\mathrm{P}=0.0257)$. Juvenile females had the longest forearms $(x=43.77$ $\mathrm{mm} \pm 0.80 \mathrm{~mm} ; \min 43.00 \mathrm{~mm} ; \max 44.60 \mathrm{~mm})$, followed by adult females $(x=43.02$ $\mathrm{mm} \pm 1.20 \mathrm{~mm} ; \min 40.60 \mathrm{~mm} ; \max 45.20 \mathrm{~mm})$, adult males $(x=42.28 \mathrm{~mm} \pm 1.22 \mathrm{~mm}$; $\min 40.50 \mathrm{~mm} ; \max 44.10 \mathrm{~mm})$ and juvenile males $(x=42.13 \mathrm{~mm} \pm 0.72 \mathrm{~mm} ; \min 40.80$ 
$\mathrm{mm} ; 43.20 \mathrm{~mm}$ ). There was no statistical association between age and forearm length $(\mathrm{P}<0.2696)$. However, heavier bats also had longer forearms $(\mathrm{P}<0.0388)$.

\subsection{Metal Analysis in Rafinesque's Big-eared bat Hair}

During banding activities for Raffnesque's big-eared bats, hair samples were collected from 56 individuals and used to assess the variation in concentration of 10 elements. Total $\mathrm{Al}, \mathrm{Cd}, \mathrm{Cr}, \mathrm{Cu}, \mathrm{Hg}, \mathrm{Ni}, \mathrm{Pb}$, and $\mathrm{Zn}$ were detected in ail hair samples; $\mathrm{As}$ was measured in 22 samples and Se was measured in 55 samples. Hair samples were not washed prior to analysis; thus external contamination may be an important source of some contamination. Table 5 shows the mean concentration of each metal according to the age and sex classes of Rafinesque's big-eared bats in South Carolina.

The concentration of mercury varied significantly between adults and juvenile big-eared bats $(\mathrm{P}<0.001)$; but not between male and female $(\mathrm{P}=0.0899)$ bats. Mercury was present in higher concentrations in adult bats ( $\mathrm{n}=40 ; x=11.04 \mu \mathrm{g} / \mathrm{g} \pm 0.03 \mu \mathrm{g} / \mathrm{g}$ ) compared to juvenile bats $(\mathrm{n}=18 ; x=5.81 \mu \mathrm{g} / \mathrm{g} \pm 0.59 \mu \mathrm{g} / \mathrm{g}$ ). Although the difference between mercury levels in the sexes was not significant, it was lower in males $(\mathrm{n}=30 ; x=$ $8.61 \mu \mathrm{g} / \mathrm{g} \pm 0.28 \mu \mathrm{g} / \mathrm{g})$ than females $(\mathrm{n}=28 ; x=10.29 \mu \mathrm{g} / \mathrm{g} \pm 0.17 \mu \mathrm{g} / \mathrm{g})$. There was no statistical association between age or sex class and the other elements. Males had higher concentrations of all heavy metals, except mercury, than female bats. However, none of these differences were statistically significant $(\mathrm{P}<0.05)$.

Bats were grouped by the area (Edisto River, Four Hole Swamp, Savannah River, Pee Dee River, Black River) where they were captured and the total metal concentration within each group was calculated according to age and sex. Total $\mathrm{Cd}(\mathrm{P}=0.0056), \mathrm{Cr}(\mathrm{P}$ $=0.0374), \mathrm{Pb}(\mathrm{P}=0.0119)$, and $\mathrm{Zn}(\mathrm{P}=0.0205)$ measured in Rafinesque's big-eared bats 
differed significantly among location (Table 5). Total mercury did not differ significantly among locations $(\mathrm{P}=0.0667)$.

\section{Discussion}

Use of bridges as roosting structures by bats is a common occurrence in the United States. At least 24 species of bats are known to use highway bridges as roosting sites (Keeley and Tuttle 1999). Use of bridges as day roosts by Rafinesque's big-eared bat may be a common occurrence throughout their range. In Louisiana, Lance et al. (2001) were the first to document the use of girder type bridges by Rafinesque's big-eared bats. Subsequentiy, this species has been found to roost under highway bridges in other states including North Carolina (Clark 1990, McDonnell 2001) and Mississippi (Trousedale and Beckett 2002). This is the first study to document the use of highway bridges by Rafinesque's big-eared bat in South Carolina.

Bridges, especially T-beam bridges, are important roosting sites for Rafinesque's big-eared bats in South Carolina. Maternal, adult and solitary groups were found to utilize this structure type frequently in the Upper and Lower Coastal Plain of South Carolina. Unlike many other bat species, which prefer to roost in expansion joints and crevices underneath bridges, Rafinesque's big-eared bat was found to roost between exposed support beams near the abutments of a bridge. This is similar to the roosting behavior reported by Rafinesque's big eared bat in Louisiana (Lance et al 2001), Mississippi (Trousedale and Beckett 2002), and North Carolina (McDonnell 2001). Roosting in exposed interbeam spaces under bridges may allow bats to more easily detect and avoid predators. In addition, roosting between beams provides the bats with ample protection from adverse weather events, such as rains and strong winds, which are 
common during the summer months in South Carolina. Provision of adequate shelter and avoidance of predators are important factors influencing the selection of roost sites by bats (Lewis 1995). Compared to slab and multi-beam bridges, T-beam bridges have the most protected interbeam spaces for a bat to roost it. Thus T-beam bridges provide Rafinesque's big-eared bats with the most suitable roosting sites of other bridge types in South Carolina, as shown by the strong association between bridge type and occupancy.

The distribution of Rafinesque's big-eared bat roosting under highway bridges in South Carolina was similar to historical records of the bats' distribution in the state. Previous records show Rafinesque's big-eared bat in the Blue Ridge, and Upper and Lower Coastal Plain provinces of South Carolina. Occupied bridges were located in the Upper and Lower Coastal Plain, but not from the Blue Ridge region. In both Coastal Plain regions, habitat loss has been extensive, particularly of mature bottomland forests containing old-growth gum ( Nyssa sp.) trees. These trees contain large cavities, which are important natural roosting structures for Rafinesque's big-eared bat in coastal areas (Clark et al. 1998). In the Upper and Lower Coastal Plains, Rafinesque's big-eared bat has adapted its roosting behavior to include highway bridges as primary roost sites. However, in the Blue Ridge region, Rafinesque's big-eared bats primarily utilize caves, abandoned mines and rock houses for roost sites; these structures are still available to big-eared bats. Thus, in the Blue Ridge region of South Carolina where natural structures are stiil available, bridges are not important toosting sites for Rafinesque's big-eared bat. This is similar to the roosting behavior of a closely related species in Utah, Townsend's bigeared bat (Corynorhinus townsendii). In areas where caves, mines, and bridges were 
available for roosting, Townsend's big-eared bat was only found in caves and mines, but not under highway bridges (Sherwin et al. 2000).

The total number of Rafinesque's big-eared bats counted in South Carolina was higher in the second year of bridge surveys than the first. Bridges were only checked once during the 2002 survey, but were checked multiple times in 2003 . By checking bridges more than once during the summer, we were more likely to detect the presence of Rafinesque's big-eared bats. This is because big-eared bats, like many other bat species, switch roosts frequently. Bats that are faithful to a primary roost will occasionally visit alternate roosts to use in case of disturbance or destruction of the primary roost (Lewis 1995). In Louisiana, Lance et al. (2001) found that female bats roosted under bridges the majority of the time, but that the proportion of days spent at a bridge roost varied from 20\%-100\% among individuals. The remaining roost days were spent in trees (Nyssa sp.). In East Texas, Rafinesque's big-eared bats were found to use artificial structures as their primary roost sites, and trees as alternate roosts (Mirowsky 1998). In the present study, we were able to gain a better idea of the frequency of bridge use in South Carolina by monitoring bridges more frequently throughout the summer. Maternal groups were observed under the same bridge $50 \%-100 \%$ of times they were checked. Solitary bats were observed under the same bridge $20 \%-100 \%$ of the time. Thus, the frequency of bridge use by Rafinesque's big-eared bat in the Coastal Plain of South Carolina is also high.

Other factors including disturbance and bridge length were found to influence selection of bridges by Rafinesque's big-eared bat. The majority of roosts were underneath bridges with a disturbance rating of 1 or 2 , which included the disturbance 
caused by traffic on top of the bridge. If there was more traffic, the level of disturbance was increased. However, disturbance underneath the bridge (footprints, graffiti, signs of human presence) may have been relatively low. It is likely that the amount of disturbance underneath a bridge is more important to the selection of bridges than the amount of disturbance caused by traffic over the bridge. Although statistically significant, the importance of bridge length in the selection of bridges by Rafinesque's big-eared bats is unclear. The majority of bats were found under bridges $100-200 \mathrm{~m}$ long. This indicates that large bridges are being used by Rafinesque's big-eared bat. Conversely, rather than preferring larger bridges, smaller bridges may not be available to Rafinesque's big-eared bat in areas where loss of natural roost sites is significant. In.Louisiana, there was no association between the presence of Rafinesque's big-eared bat and bridge length or width (Lance et al. 2001).

Banding activities of Rafinesque's big-eared bat conducted in 2003 represents the first step in the long-term monitoring of this species. This also represents the first effort in the United States to monitor populations of Rafinesque's big-eared bat on a statewide scale. Both the aluminum bands and the plastic bands used in this study are long lasting, and allow roosting bats to be easily identified at a distance. By tagging Rafinesque's bigeared bats, we are now able to identify individuals and gain a more thorough understanding of many fundamental aspects of their ecology including small and large scale movements, roosting behaviors, reproductive cycles, lifespan, and site fidelity. For example, by tagging and subsequently recapturing or resighting the same individuals in this study, we were able to determine that reproductively active females remain within a maternal group of the same group size, and that these are likely the same individuals. 
Furthermore, through long-term monitoring, the pattern of population cycles in response to important environmental conditions, such as drought and habitat loss may be better understood.

The exposure of Rafinesque's big-eared bat to heavy metals was evaluated using hair tissue. This study is the first to measure trace elements in Rafinesque's big-eared bats, and may provide insight into the potential decline of this species in South Carolina. Previous studies have shown the presence of elevated levels of contaminants in bats including mercury and other trace elements (O'Shea et al. 2001, Hickey et al. 2001). Hickey et al. (2001) tested bat hair for the presence of the same metals that were selected for this study ( $\mathrm{Al}, \mathrm{As}, \mathrm{Cd}, \mathrm{Cr}, \mathrm{Cu}, \mathrm{Hg}, \mathrm{Ni}, \mathrm{Pb}, \mathrm{Se}, \mathrm{Zn}$ ), and detected $\mathrm{Al}, \mathrm{Hg}, \mathrm{Pb}, \mathrm{Se}$, and $\mathrm{Zn}$ in the majority of samples. In Rafinesque's big-eared bats, elevated levels of $\mathrm{Al}, \mathrm{Cd}$, $\mathrm{Cr}, \mathrm{Cu}, \mathrm{Hg}, \mathrm{Ni}, \mathrm{Pb}$, and $\mathrm{Zn}$ were measured in all hair samples, and $\mathrm{As}$ and $\mathrm{Se}$ in the majority of samples.

Other than $\mathrm{Cu}, \mathrm{Se}$, and $\mathrm{Zn}$, the remaining metals measured in Rafinesque's bigeared bats are considered to be non-essential for physiological processes (Goyer and Clarkson 2001). However, these metals can be toxic to an organism if present in sufficient concentrations; unfortunately there is no baseline data available to determine if the levels of $\mathrm{Cu}, \mathrm{Se}$, and $\mathrm{Zn}$ found in Rafinesque's big-eared bats can be considered toxic. Nevertheless, compared to levels found in little brown bats (Myotis lucifugus) from Ontario and Quebec, Canada (Hickey et al. 2001), the concentrations of Al and $\mathrm{Zn}$ in bigeared bats was higher in all samples, while levels of Se in big-eared bats was lower. Of note are the levels of Al in Rafinesque's big-eared bats; Al concentrations are an order of 
magnitude higher in big-eared bats in South Carolina compared to the bats in Ontario and Quebec. Cu was not detected in any of the $M$. lucifugus hair samples.

The presence of non-essential elements in the tissue of Rafinesque's big-eared bats indicates that uptake of these elements from the environment is occurring. Of particular concern are the elevated levels of $\mathrm{Pb}$ and $\mathrm{Hg}$, both which are considered to be highly toxic to wildlife. In Australia, levels of $\mathrm{Pb}$ in the hair of fruit bats (Pteropus sp.) that reached levels considered to be toxic ranged from $5.6 \mu \mathrm{g} / \mathrm{g}$ to $42.1 \mu \mathrm{g} / \mathrm{g}$ (Hariono et al. 1993). Lead in the hair of bats we captured ranged in concentration from $1.09 \mu \mathrm{g} / \mathrm{g}-$ $18.82 \mu \mathrm{g} / \mathrm{g}$. Overall, 14 of the 58 hair samples collected from Rafinesque's big-eared bats in South Carolina had $\mathrm{Pb}$ levels greater than $5.6 \mu \mathrm{g} / \mathrm{g}$, the lower limit of toxicity. Consequently, it is likely that $\mathrm{Pb}$ toxicity is adversely affecting populations of Rafinesque's big-eared bats in South Carolina.

Mercury in the hair of Rafinesque's big-eared bats from South Carolina ranged in concentration from $0.72 \mu \mathrm{g} / \mathrm{g}$ to $22.93 \mu \mathrm{g} / \mathrm{g}$. Although there is no information on the level of $\mathrm{Hg}$ in hair considered to be toxic to bats, the concentrations of $\mathrm{Hg}$ we measured in Rafinesque's big-eared bat are within the range of those reported from the hair of people and river otters that consume $\mathrm{Hg}$-contaminated fish (Flemming et al. 1995, Halbrook et al. 1994). Mercury concentration was measured in a single Rafinesque's big-eared bat foraging in a $\mathrm{Hg}$ contaminated area of Arkansas, and was found to be relatively low (1.227 mg/kg; Grippo and Massa 2000). In Rafinesque's big-eared bat from South Carolina, 32 of 58 hair samples had Hg concentrations that approached or exceeded 10 $\mathrm{mg} / \mathrm{kg}$, the threshold at which detrimental effects have been detected in humans and 
rodents (Murata et al. 1999, Burton et al. 1977). As a result, Hg is likely causing adverse effects on Rafinesque's big-eared bats in South Carolina.

\section{Management Recommendations}

Availability of adequate roosting sites is an important component underlying the distribution and abundance of bats (Lewis 1995). Thus, efforts to protect Rafinesque's big-eared bat in South Carolina should begin with the protection of roosting structures.

For big-eared bats that use highway bridges as roost sites in South Carolina, management efforts should include protecting occupied bridges and improving the usefulness of additional bridges within the species range. Protection of bridges can only be accomplished by working closely with the South Carolina DOT, to ensure that potential construction on bridges and that the alternation of habitat adjacent to a bridge is reduced. If construction is necessary a bridge should be monitored to ensure that bats are not occupying it, and if they are present, efforts should be taken to either wait until the bats are no longer present (e.g. during the non-breeding season), or to make another structure suitable so as to provide an alternate roost. In addition, the practice of removing much of the vegetation surrounding a bridge during the summer months should be halted. This disturbance may cause Rafinesque's big-eared bats to abandon their roosts or pups and may also reduce the suitability of a bridge for bats. By maintaining adequate vegetative cover around a bridge it also becomes less accessible to humans and consequently there may be a lower incidences of human-related disturbances under the bridge. Protection of bridges as roosting sites is important in maintaining populations of Rafinesque's big-eared bat in South Carolina. 
In addition to roost site protection, efforts to conserve the population of Rafinesque's big-eared bat in South Carolina should include regular monitoring of their exposure to environmental contaminants. As we have shown, it is likely that mercury and lead are causing adverse effects to big-eared bats in the state. Although the effects of these metals on the bats requires further study, a better understanding of the variation in the concentrations of trace metals and other compounds would assist in determining the role environmental contaminants play in the possible decline of this species. 


\section{Literature Cited}

Anthony ELP. 1988. Age determination in bats. Pages 47-58 in TH Kunz, editor.

Ecological and behavioral methods for the study of bats. Smithsonian Institution

Press. Washington, D.C. 533 pp.

Bagely FM. 1984. A recovery plan for the Ozark big-eared bat and the Virginia big-eared bat. United States Fish and Wildlife Service. Twin Cities, Minnesota. 56 pp.

Barbour R, Davis W. 1969. Bats of North America. The University Press of Kentucky, Lexington, KY. 286 pp.

Burton GV, Alley RJ, Rasmussen L, Orton P, Cox V, Jones P, Graff D. 1977. Mercury and behavior in wild mouse populations. Environmental Research. 14:30-34.

Clark DR Jr, LaVal RK, Swineford DM. 1978. Dieldrin-induced mortality in an endangered species, the gray bat (Myotis griscens). Sctence. 199(4335):13571359.

Clark DR Jr., Morena-Valdez A, Mora MA. 1995. Organochlorine residues in bat guano from nine Mexican caves, 1991. Ecotoxicology. 4(4):258-265.

Clark DR Jr. 2001. DDT and the decline of free-tailed bats (Tadarida brasiliensis) at Carlsbad Cavern, New Mexico. Archives of Environmental Contamination and Toxicology. 40(4):537-543.

Clark MK. 1990. Roosting ecology of the eastern big-eared bat (Plecotus rafinesquii), in North Carolina. MS Thesis. North Carolina State University at Raleigh, Raleigh, North Carolina. $111 \mathrm{pp}$.

Clark MK, Black A, Kiser M. 1998. Roosting and foraging activities of Corynorhinus rafinesquil in the Francis Beidler Forest in South Carolina. Bat Research News. $39(4): 162-163$.

Fernandez MA, Hernandez LM, Ibanez C, Gonzalez MJ, Guillen A, Perez JL. 1993. Congeners of PCBs in three bat species from Spain. Chemosphere. 26(6):10851097.

Flemming LE, Watkins S, Kaderman R, Levin B, Ayyar DR, Bizzio M, Stephens D, Bean JA. 1995. Mercury exposure in humans through food consumption from the Everglades of Florida. Water Air and Soil Pollution. 80(1):41-48.

Gerell R, Lundberg KG. 1993. Decline of a bat (Pipistrellus pipistrellus) population in an industrialized area in south Sweden. Biological Conservation. 65(2):153-157. 
Goyer RA, Clarkson TW. 2001. Toxic Effects of Metals. Pages 811-867 in CD Klaassen, editor. Casarett and Doull's Toxicology: The Basic Science of Poisons, $6^{\text {th }}$ Edition. McGraw-Hill Companies, Inc, Medical Publishing Division, New York, New York.

Grippo RS, Massa SA. 2000. Mercury in free-ranging bats collected from fishconsumption advisory areas in Arkansas. A report to the Arkansas Game and Fish Commission. 65 pp.

Halbrook RS, Jenkins JH, Bush PB, Seabolt ND. 1994. Sublethal concentrations of mercury in river otters: monitoring environmental contamination. Archives of Environmental Contamination and Toxicology. 27:306-310.

Hariono B, Ng J, Sutton RH. 1993. Lead concentrations in tissues of Fruit bats in urban and non-urban locations. Wildlife Research. 20:315-320.

Hickey MBC, Fenton MB, MacDonald KC, Soulliere C. 2001. Trace elements in the fur of bats (Chiroptera: Vespertilionidae) from Ontario and Quebec, Canada. Bulletin of Environmental Contamination and Toxicology. 66(6):699-706.

Hoffinan V, Cochran S, Wilhide JD, King S. 1998. Roost selection of female Myotis austroriparius and Corynorhinus rafinesquii in a bottomland hardwood forest. Bat Research News. 39(4):174.

Hoffman DJ, Rattner BA, Scheunert I, Korte F. 2001. Environmental Contaminants. Pages 1-48 in RF Shore and BA Rattner, editors. Ecotoxicology of Wild Mammals. John Wiley and Sons, Ltd, New York, New York.

Hurst TE, Lacki MJ. 1997. Food habits of Rafinesque's big-eared bat in southeastern Kentucky. Journal of Mammalogy 78(2): 525-528.

Hurst, TE, Lacki MJ. 1999. Roost selection, population size and habitat use by a colony of Rafinesque's big-eared bats (Corynorhinus rafinesquii). American Midland Naturalist 142(2): 363-371.

Jones, C., and R D. Suttkus. 1975. Notes on the natural history of Plecotus rafinesquii. Louisiana State University Occasional Paper, Museum of Zoology 47:1-14.

Keeley BW, Tuttle MD. 1999. Bats in American Bridges. Resource Publication Number 4. Bat Conservation International, Austin, TX, $23 \mathrm{pp}$.

Kunz TH, Kurta A. 1988. Capture methods and holding devices. Pages 1-29 in TH Kunz, editor. Ecological and behavioral methods for the study of bats. Smithsonian Institution Press. Washington, D.C. pp 1. 
Lacki MJ. 2000. Effect of trail users at a maternity roost of Rafinesque's big-eared bats. Journal of Cave and Karst Studies. 62(3):163-168.

Lance RF, Leberg PL. 1999. Interpopulation mtDNA diversity in Corynorhinus rafinesquii. Bat Research News. 40(4):178-179.

Lance RF, Hardcastle BT, Talley A, Leberg PL. 2001. Day-roost selection by Rafinesque's big-eared bats (Corynorhinus rafinesquii) in Louisiana forests. Journal of Mammalogy. 82(1):166-172.

Lewis SE. 1995. Roost fidelity of bats: a review. Joumal of Mammalogy. 76(2): 481-496.

Martin CO, Mitchell WA, Wolters MS. 2002. Eastern cave- and crevice-dwelling bats potentiaily impacted by USACE reservoir operations. EMRRP Technical Notes Collection (ERDC TN EMRRP-SI-24). U.S. Army Engineer Research and Development Center, Vicksburg, Mississippi. 11 pp.

McCracken GF. 1989. Cave conservation: Special problems of bats. National Speleological Society Bulletin. 51(1):47-51.

McDonnell JM. 2001. Use of bridges as day roosts by bats in the North Carolina coastal plain. MS Thesis. North Carolina State University at Raleigh, Raleigh, North Carolina. $74 \mathrm{pp}$.

Menzel JM, Menzel MA, Ford WM, Edwards JW, Sheffield SR, Kilgo JC, Bunch MS. 2003. The distribution of the bats of South Carolina. Southeastern Naturalist. 2(1):121-152.

Menzel MA Menzel MA Ford WM, Edwards JW, Carter TC, Churchill JB, Kilgo, JC. 2001. Home range and habitat use of male Rafinesque's big-eared bats (Corynorhinus rafinesquii). American Midland Naturalist 145(2): 402-408.

Mirowsky KM. 1998. Roosting Ecology of the Southeastern Myotis (Myotis austroriparius) and Rafinesque's Big-eared Bat (Corynorhinus rafinesquii) in East Texas. MS Thesis. Texas A\&M University, Texas. 75 pp.

Murata K. Weihe P, Araki S, Budtz-Jorgensen E, Grandjean P. 1996. Evoked potentials in Faroese children prenatally exposed to methyl mercury. Neurotoxicology and Teratology. 21: 471-472.

O'Shea TJ, Everette AL, Ellison LE. 2001. Cyclodiene insecticide, DDE, DDT, arsenic and mercury contamination of big brown bats (Episticus fuscus) foraging at a Colorado superfund site. Archives of Environmental Contamination and Toxicology. 40(1):112-120. 
Racey PA. 1998. Reproductive assessment in bats, Pages 31-43 in TH Kunz, editor. Ecological and behavioral methods for the study of bats. Smithsonian Institution Press. Washington, D.C. 533 pp.

Sherwin RE, Strickland D, Rogers DS. 2000. Roosting affinities of Townsend's big-eared bat (Corynorhinus townsendii) in Northern Utah. Journal of Mammalogy. 81(4): 939-947.

Shore RF, Myhill DG, French MC, Leach DV, Stebbings RE. 1991. Toxicity and tissue distribution of pentachlorophenol and permethrin in pipistrelle bats experimentally exposed to treated timbet. Environmental Pollution. 73(1):101118.

South Carolina Department of Natural Resources. 2001. Rankings of terrestrial mammals for South Carolina's endangered, threatened, and special concern list. South Carolina Department of Natural Resources, Pendleton, SC. 2 pp.

Stebbings RE, Griffiths F. 1986. Distribution and status of bats in Europe. Institute of Terrestrial Ecology, Huntingdon, UK.

Trousedale AW, Beckett DC. 2002. Bats (Mammalia: Chiroptera) recorded from mist-net and bridge surveys in southern Mississippi. Journal of the Mississippi Academy of Sciences, 47(4):183-189.

United States Fish and Wildlife Service. 1996a. 50 CFR Part 17. Endangered and threatened wildlife and plants; review of plant and animal taxa that are candidates for listing as endangered or threatened species. Federal Register 61(40):75967613.

United States Fish and Wildlife Service. 1996b. 50 CFR Part 17. Endangered and threatened wildlife and plants; notice of final decision on identification of candidates for listing as endangered or threatened. Federal Register 61(235): 64481-64485.

United States Fish and Wildlife Service. 1989. 50 CFR Part 17. Endangered and threatened wildlife and plants: Animal notice of review. Federal Register 54 (554): $1-124$

Waldien DL, Hayes JP. 1999. A technique to capture bats using hand-held mist nets. Wildlife Society Bulletin. 27(1):197-200. 
Table 1. State protection status of Rafinesque's big-eared bat (Corynorhinus rafinesquii) in the United States.

\begin{tabular}{|c|c|}
\hline State & Status \\
\hline \multicolumn{2}{|c|}{ Midwest/Central States } \\
\hline Illinois & State Endangered \\
\hline Indiana & Species of Special Concern \\
\hline Missouri & Species of Special Concern \\
\hline Ohio & Species of Special Concem \\
\hline Oklahoma & Species of Special Concern \\
\hline Texas & State Threatened \\
\hline \multicolumn{2}{|c|}{ Southeast States } \\
\hline Alabama & State Protected \\
\hline Arkansas & Species of Special Concern \\
\hline Florida & Species of Special Concern \\
\hline Georgia & Species of Special Concern \\
\hline Kentucky & Species of Special Concern \\
\hline Mississippi & Species of Special Concern \\
\hline North Carolina & Species of Special Concern \\
\hline South Carolina & State Endangered \\
\hline Tennessee & Species of Special Concern \\
\hline \multicolumn{2}{|c|}{ Northeast States } \\
\hline Virginia & State Endangered \\
\hline West Virginia & Species of Special Concern \\
\hline
\end{tabular}




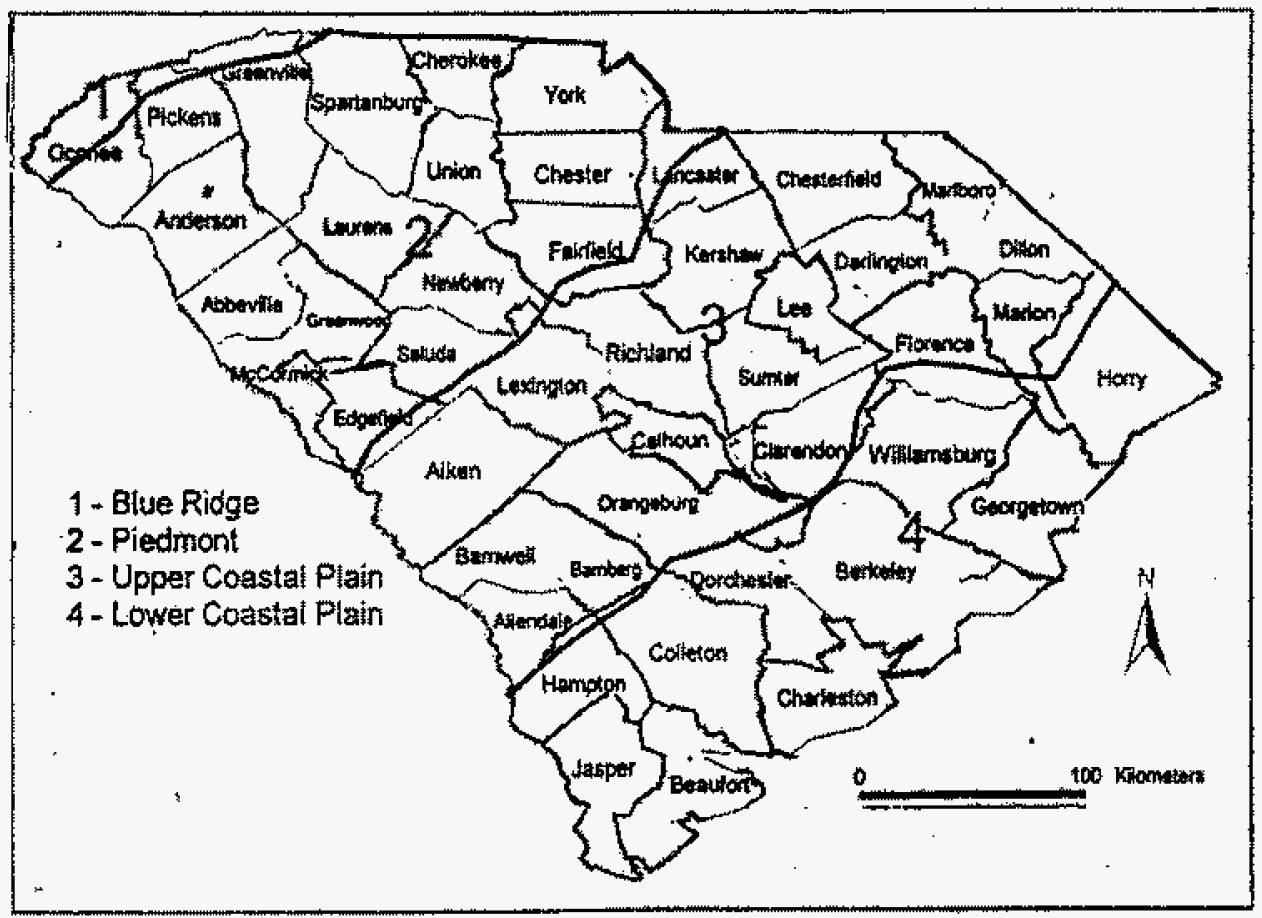

Figure 1. The four physiographic provinces of South Carolina.

(From Menzel et al. 2003). 

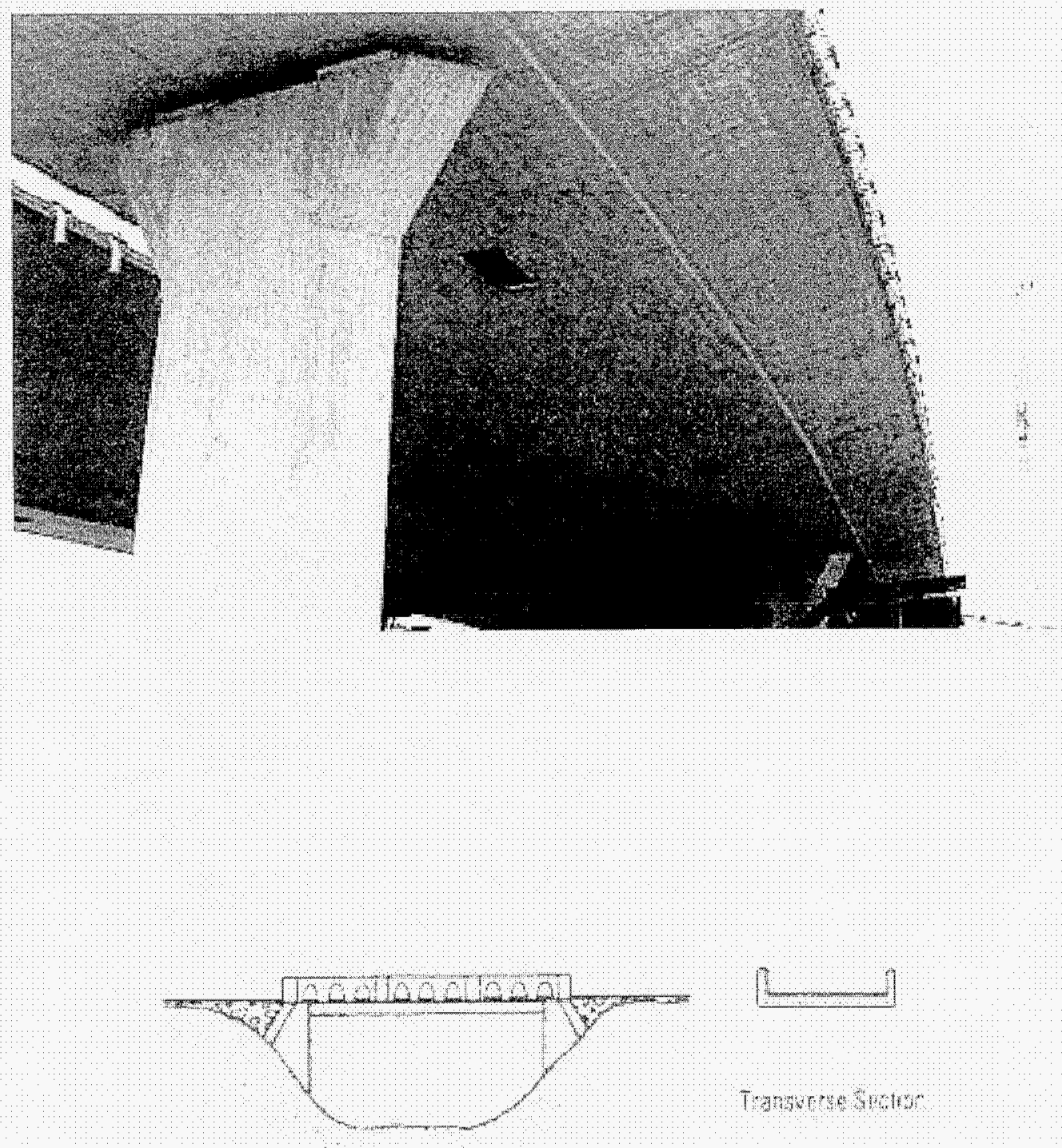

Howith

Figure 2. Photograph (above) and diagram (below) of a concrete slab bridge commonly found in South Carolina. (Source: Historic Bridge Foundation, Austin, TX). 

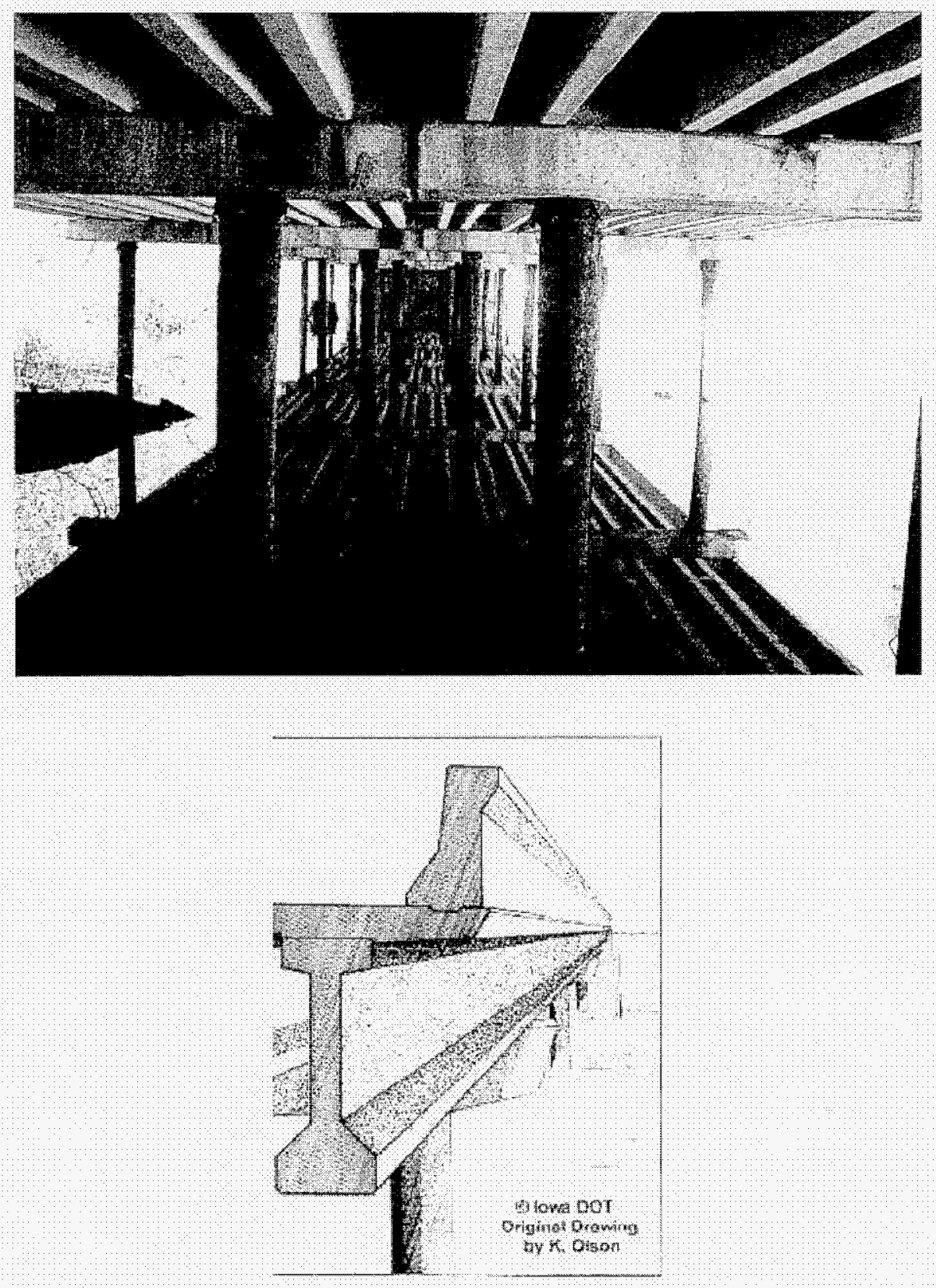

Figure 3. Photograph (above) of a typical multi-beam bridge in South Carolina. The diagram below shows construction details of common multi-beam type bridge, known as an I-beam (Source: Iowa DOT). 

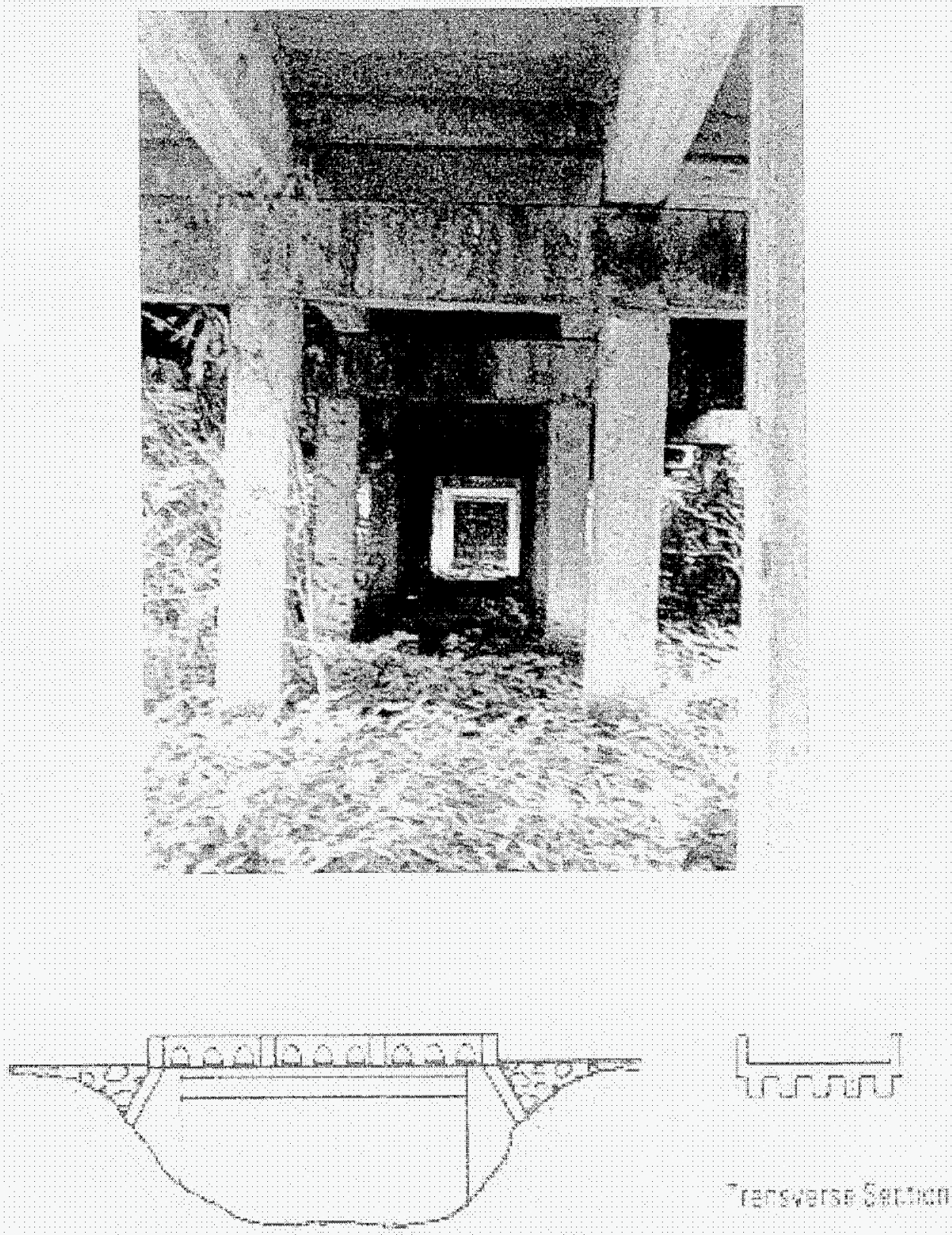

Frowtht

Figure 4. Photograph (above) of a typical T-beam bridge in South Carolina. The diagram (below) shows construction details of T-beam bridges, also known as concrete girder bridges (Source: Historic Bridge Foundation, Austin, TX), 
Table 2. Abundance of highway bridges in each county of South Carolina and the number of bridges surveyed for Rafinesque's big-eared bat in 2002 .

\begin{tabular}{|c|c|c|c|c|c|c|}
\hline County & $\begin{array}{c}\text { No. } \\
\text { Slab } \\
\text { Bridges } \\
\text { Present }\end{array}$ & $\begin{array}{c}\text { No. Slab } \\
\text { Bridges } \\
\text { Surveyed }\end{array}$ & $\begin{array}{c}\text { No. } \\
\text { Multi- } \\
\text { Beam } \\
\text { Bridges } \\
\text { Present }\end{array}$ & $\begin{array}{c}\text { No. } \\
\text { Multi- } \\
\text { Beam } \\
\text { Bridges } \\
\text { Surveyed }\end{array}$ & $\begin{array}{c}\text { No. T- } \\
\text { beam } \\
\text { Bridges } \\
\text { Present }\end{array}$ & $\begin{array}{c}\text { No. T- } \\
\text { beam } \\
\text { Bridges } \\
\text { Surveyed }\end{array}$ \\
\hline Abbeville & 63 & 1 & 54 & 3 & 14 & 14 \\
\hline Aiken & 60 & 7 & 21 & 10 & 18 & 15 \\
\hline Allendale & 51 & 7 & 1 & 1 & 5 & 4 \\
\hline Anderson & 141 & 8 & 177 & 15 & 34 & 34 \\
\hline Bamberg & 57 & 4 & 5 & 5 & 14 & 14 \\
\hline Barnwell & 51 & 4 & 1 & 1 & 9 & 8 \\
\hline Beaufort & 24 & 2 & 15 & 4 & 5 & 3 \\
\hline Berkeley & 111 & 7 & 14 & 11 & 7 & 7 \\
\hline Calhoun & 18 & 2 & 2 & 1 & 5 & 4 \\
\hline Charleston & 93 & 1 & 20 & 3 & 12 & 6 \\
\hline Cherokee & 56 & 1 & 88 & 13 & 11 & 10 \\
\hline Chester & 86 & 1 & 36 & 6 & 10 & 0 \\
\hline Chesterfield & 114 & 0 & 31 & 10 & 18 & 10 \\
\hline Clarendon & 94 & 0 & 9 & 8 & 7 & 5 \\
\hline Colleton & 153 & 42 & 16 & 4 & 15 & 2 \\
\hline Darlington & 105 & 7 & 12 & 10 & 14 & 13 \\
\hline Dillon & 72 & 0 & 2 & 2 & 8 & 7 \\
\hline Dorchester & 113 & 1 & 4 & 3 & 15 & 13 \\
\hline Edgefield & 50 & 1 & 48 & 22 & 8 & 8 \\
\hline Fairfield & 51 & 1 & 40 & 9 & 2 & 1 \\
\hline Florence & 136 & 10 & 23 & 14 & 12 & 11 \\
\hline Georgetown & 74 & 7 & 11 & 5 & 3 & 3 \\
\hline Greenville & 126 & 4 & 189 & 19 & 39 & 36 \\
\hline Greenwood & 77 & 3 & 28 & 0 & 7 & 7 \\
\hline Hampton & 76 & 5 & 3 & 1 & 10 & 10. \\
\hline Horry & 229 & 18 & 19 & 14 & 14 & 10 \\
\hline Jasper & 57 & 8 & 4 & 4 & 17 & 19 \\
\hline Kershaw & 84 & 3 & 27 & 18 & 9 & 6 \\
\hline Lancaster & 58 & 2 & 41 & 6 & 46 & 32 \\
\hline Laurens & 91 & 3 & 74 & 3 & 20 & 18 \\
\hline Lee & 52 & 1 & 7 & 6 & 2 & 2 \\
\hline Lexington & 82 & 6 & 33 & 14 & 9 & 8 \\
\hline McCormick & 21 & 1 & 21 & 9 & 7 & 7 \\
\hline Marion & 56 & 3 & 3 & 4 & 25 & 25 \\
\hline Marlboro & 46 & 0 & 6 & 2 & 19 & 16 \\
\hline
\end{tabular}


Table 2 (continued). Abundance of highway bridges in each county of South Carolina and the number of bridges surveyed for Rafinesque's big-eared bat in 2002 .

\begin{tabular}{|c|c|c|c|c|c|c|}
\hline County & $\begin{array}{c}\text { No. } \\
\text { Slab } \\
\text { Bridges } \\
\text { Present }\end{array}$ & $\begin{array}{l}\text { No. Slab } \\
\text { Bridges } \\
\text { Surveyed }\end{array}$ & $\begin{array}{c}\text { No. } \\
\text { Multi- } \\
\text { Beam } \\
\text { Bridges } \\
\text { Present }\end{array}$ & $\begin{array}{c}\text { No. } \\
\text { Multi- } \\
\text { Bearn } \\
\text { Bridges } \\
\text { Surveyed }\end{array}$ & $\begin{array}{l}\text { No. T- } \\
\text { beam } \\
\text { Bridges } \\
\text { Present }\end{array}$ & $\begin{array}{c}\text { No. T- } \\
\text { beam } \\
\text { Bridges } \\
\text { Surveyed }\end{array}$ \\
\hline Newberry & 90 & 2 & 66 & 16 & 14 & 11 \\
\hline Oconee & 77 & 3 & 67 & 6 & 18 & 18 \\
\hline Orangeburg & 124 & 11 & 9 & 8 & 45 & 41 \\
\hline Pickens & 122 & 1 & 77 & 4 & 13 & 12 \\
\hline Richland & 89 & 0 & 31 & 6 & 19 & 13 \\
\hline Saluda & 68 & 3 & 36 & 17 & 13 & 13 \\
\hline Spartanburg & 124 & 4 & 197 & 8 & 47 & 41 \\
\hline Sumter & 94 & 0 & 7 & 7 & 16 & 13 \\
\hline Union & 57 & 0 & 43 & 6 & 10 & 6 \\
\hline Williamsburg & 156 & 7 & 7 & 6 & 10 & 9 \\
\hline York & 134 & 1 & 48 & 2 & 18 & 15 \\
\hline Total & 3963 & 203 & 1673 & 346 & 693 & 580 \\
\hline$\%$ Surveyed & - & 5.12 & - & 20.68 & - & 83.69 \\
\hline
\end{tabular}




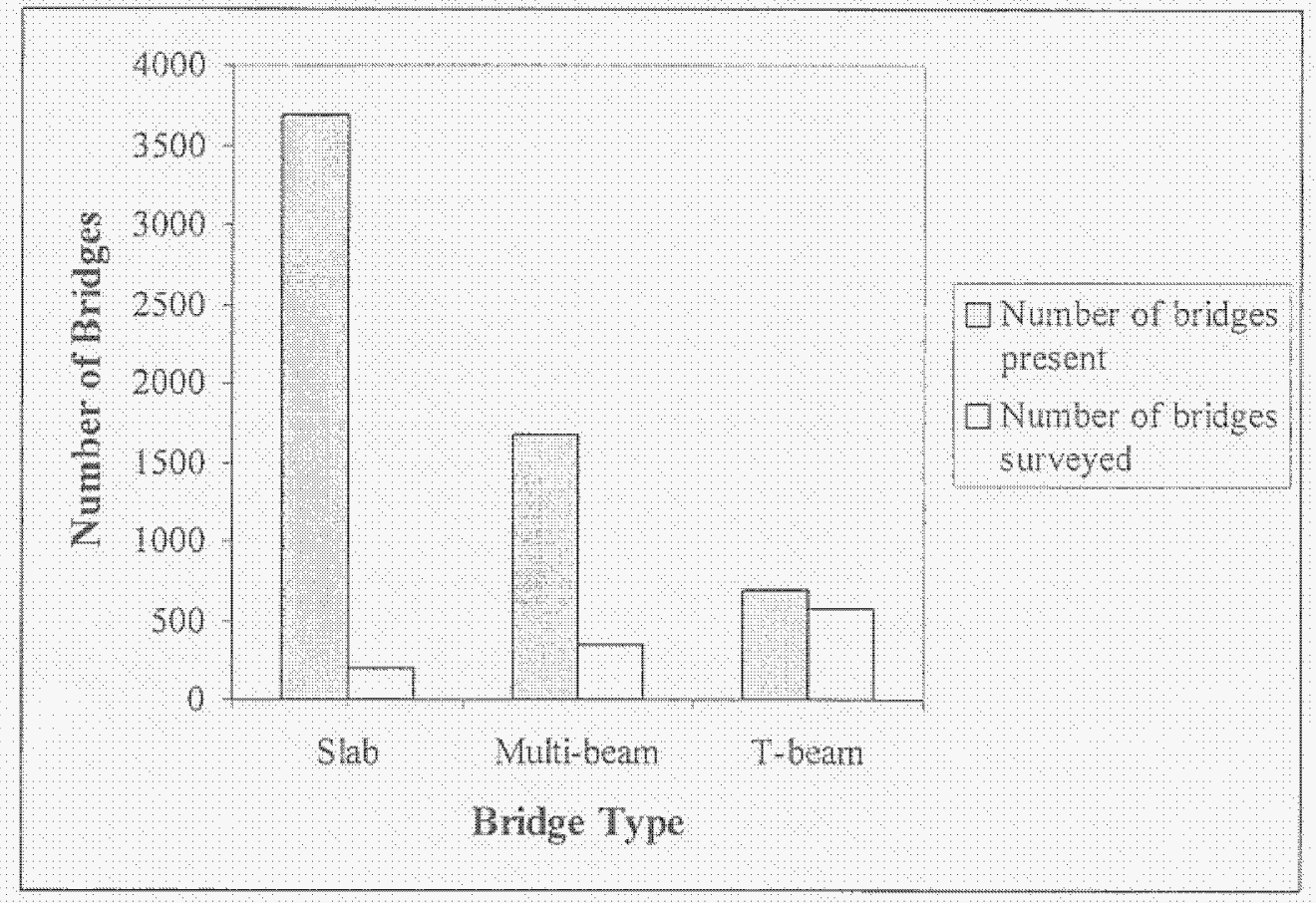

Figure 5. Number of bridges present and surveyed for Rafinesque's big-eared bat (Corynorhinus rafinesquii) in South Carolina, 2002. The percent of each bridge type surveyed compared to the total number present was: slab $5.50 \%$; multi-beam $20.68 \%$ and T-beam $83.69 \%$. 

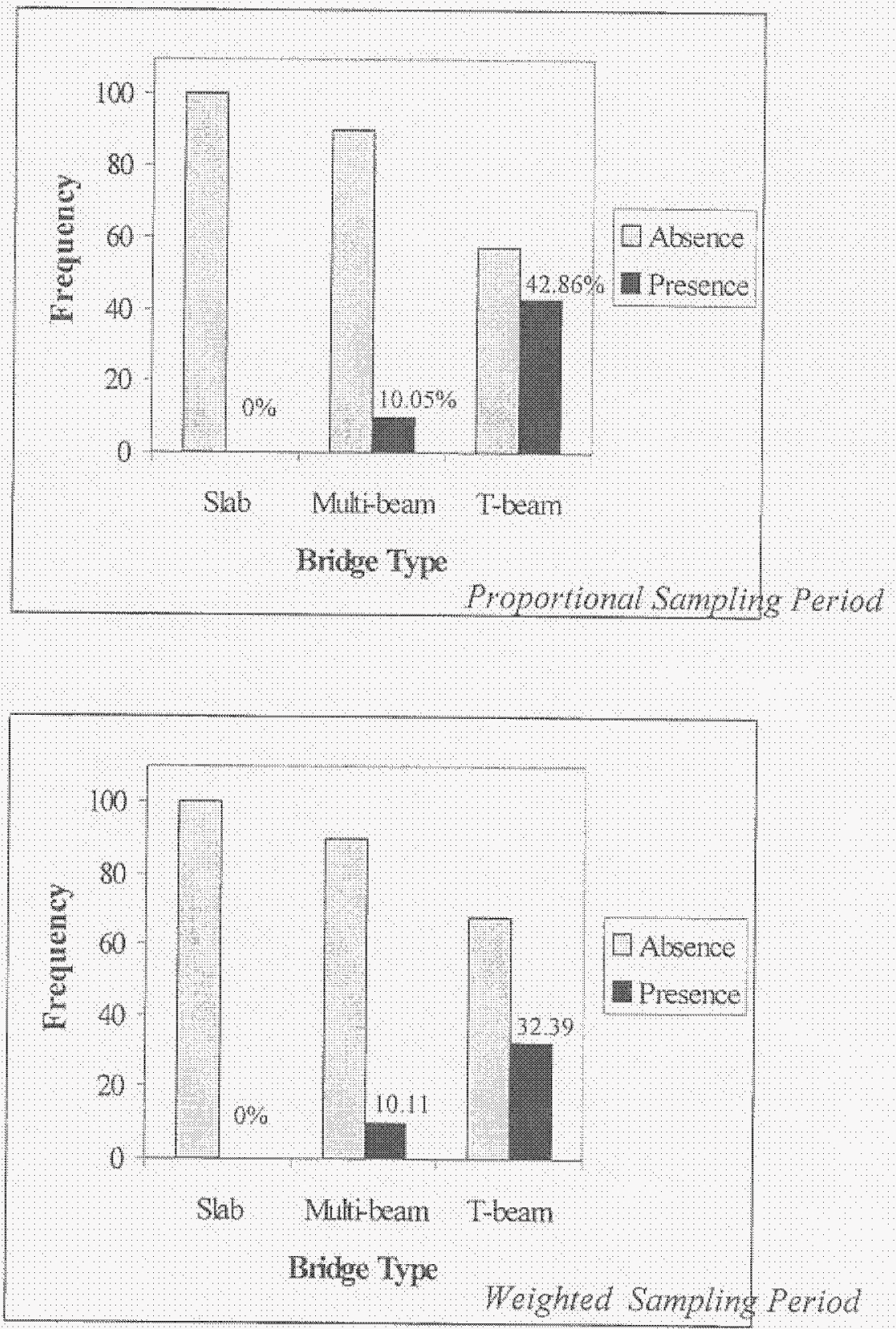

Figure 6. Absence and presence of Rafinesque's big-eared bat (Corynorhinus rafinesquii) under highway bridges in South Carolina in 2002. The top graph shows the pattern of bridge occupancy during the initial sampling period; the bottom graph shows the same pattem of occupation found during the weighted sampling period. The percent of occupied bridges is shown above the corresponding bar. 


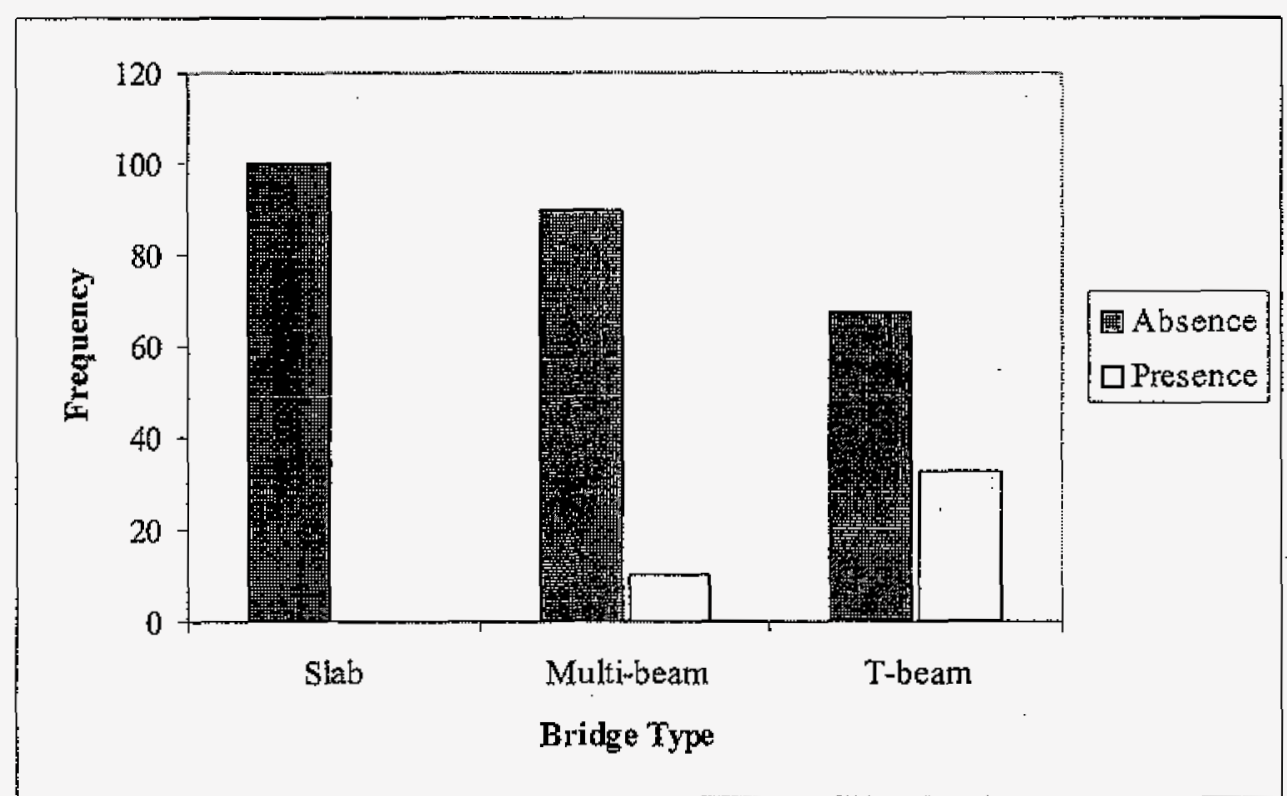

Figure 7. Distribution of Rafinesque's big-eared bat (Corynorhinus rafinesquii) roosts under highway bridges in South Carolina, 2002. Rafinesque's big-eared bat demonstrate a highly significant relationship between bridge type and occupancy $(P<0.001)$. 


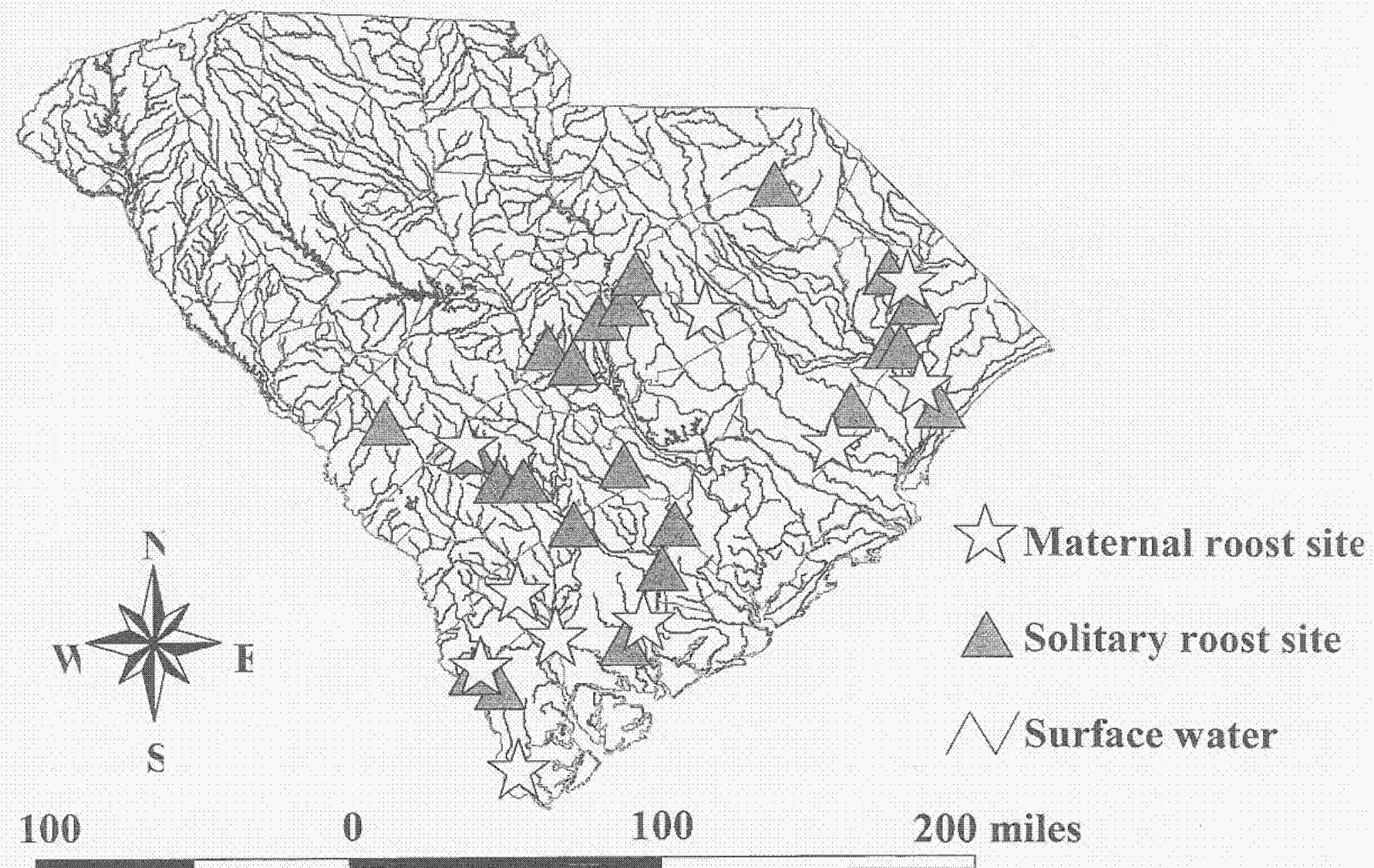

Figure 8. The location of maternal and solitary roosts of Rafinesque"s big-eared bats (Corynorhinus rafinesquii) located under highway bridges in South Carolina, 2002. 
Table 3. Roost types of Rafinesque's big-eared bats and their guano found under bridges in South Carolina in 2002. Roosts are grouped according to the four physiographic regions of South Carolina. Guano was collected from bridges and not from roosts or individuals.

Physiographic Province

\begin{tabular}{cccccccccc}
\hline & Blue Ridge & Piedmont & \multicolumn{2}{c}{ Upper Coastal Plain } & \multicolumn{2}{c}{ Lower Coastal Plain } \\
\hline Maternal Roosts & No. Bridges & No. Bridges & No. & No. & No. & No. & No. & No. \\
& & & Bridges & Roosts & Bats & Bridges & Roosts & Bats \\
\hline Slab & 0 & 0 & 0 & 0 & 0 & 0 & 0 & 0 \\
\hline Multibeam & 0 & 0 & 0 & 0 & 0 & 0 & 0 & 0 \\
\hline T-Beam & 0 & 0 & 7 & 9 & 108 & 6 & 7 & 88 \\
\hline Solitary Roosts & & & & & & & & \\
\hline Slab & 0 & 0 & 0 & 0 & 0 & 0 & 0 & 0 \\
\hline Multibeam & 0 & 0 & 5 & 6 & 6 & 1 & 1 & 1 \\
\hline T-Beam & 0 & 0 & 16 & 24 & 24 & 11 & 20 & 20 \\
\hline Guano & & & & & & & & \\
\hline Slab & 0 & 0 & 0 & $\mathrm{n} / \mathrm{a}$ & $\mathrm{n} / \mathrm{a}$ & 0 & $\mathrm{n} / \mathrm{a}$ & $\mathrm{n} / \mathrm{a}$ \\
\hline Multibeam & 0 & 2 & 7 & $\mathrm{n} / \mathrm{a}$ & $\mathrm{n} / \mathrm{a}$ & 5 & $\mathrm{n} / \mathrm{a}$ & $\mathrm{n} / \mathrm{a}$ \\
\hline T-Beam & 0 & 5 & 77 & $\mathrm{n} / \mathrm{a}$ & $\mathrm{n} / \mathrm{a}$ & 19 & $\mathrm{n} / \mathrm{a}$ & $\mathrm{n} / \mathrm{a}$ \\
\hline
\end{tabular}




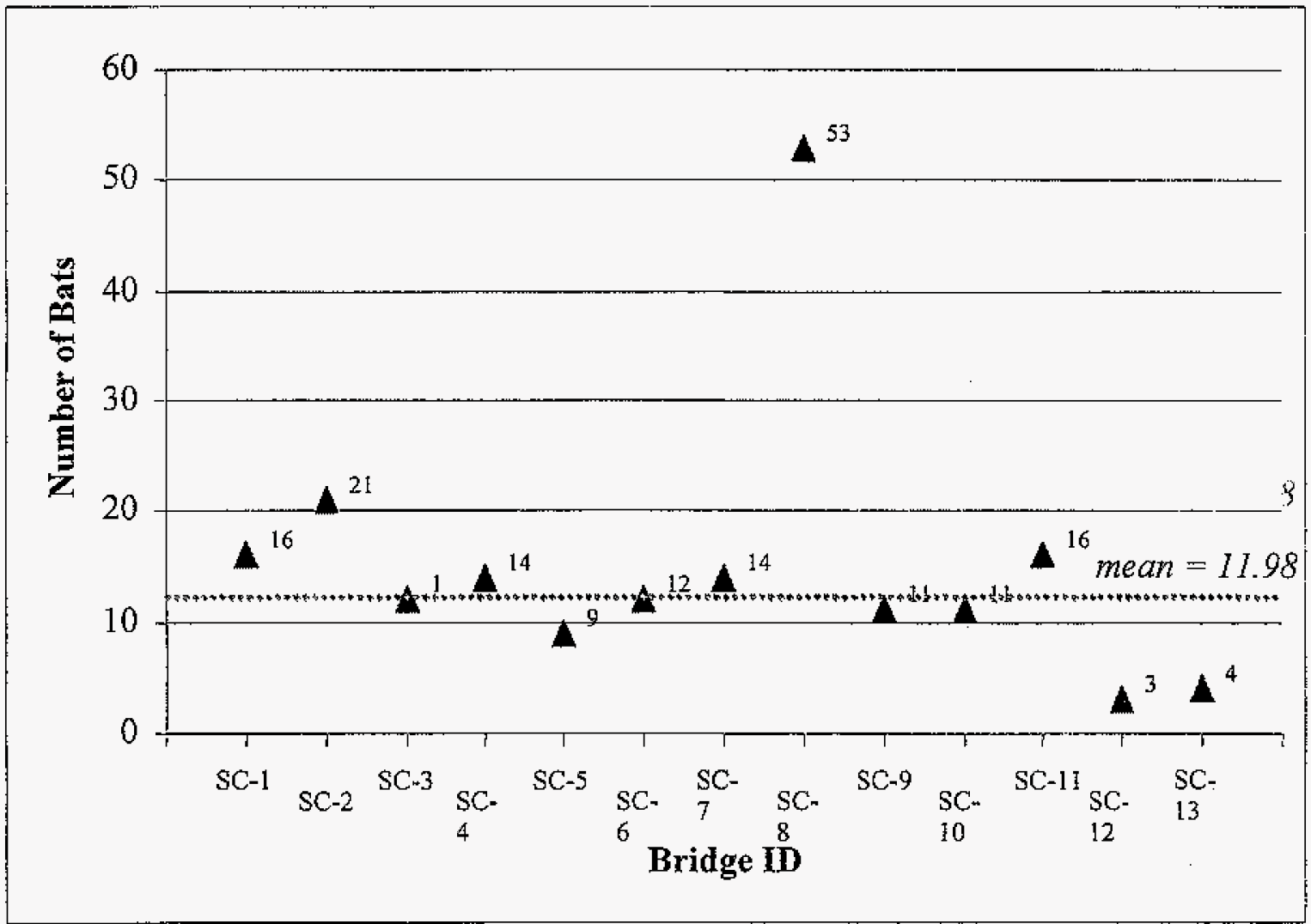

Figure 9. Numbers of Rafinesque's big-eared bats (Corynorhinus rafinesquii) counted in matemal roosts under highway bridges in South Carolina, 2002. The number of bats in each roost is indicated by each point; $x=11.98$; std dev $=12.37$ ). 


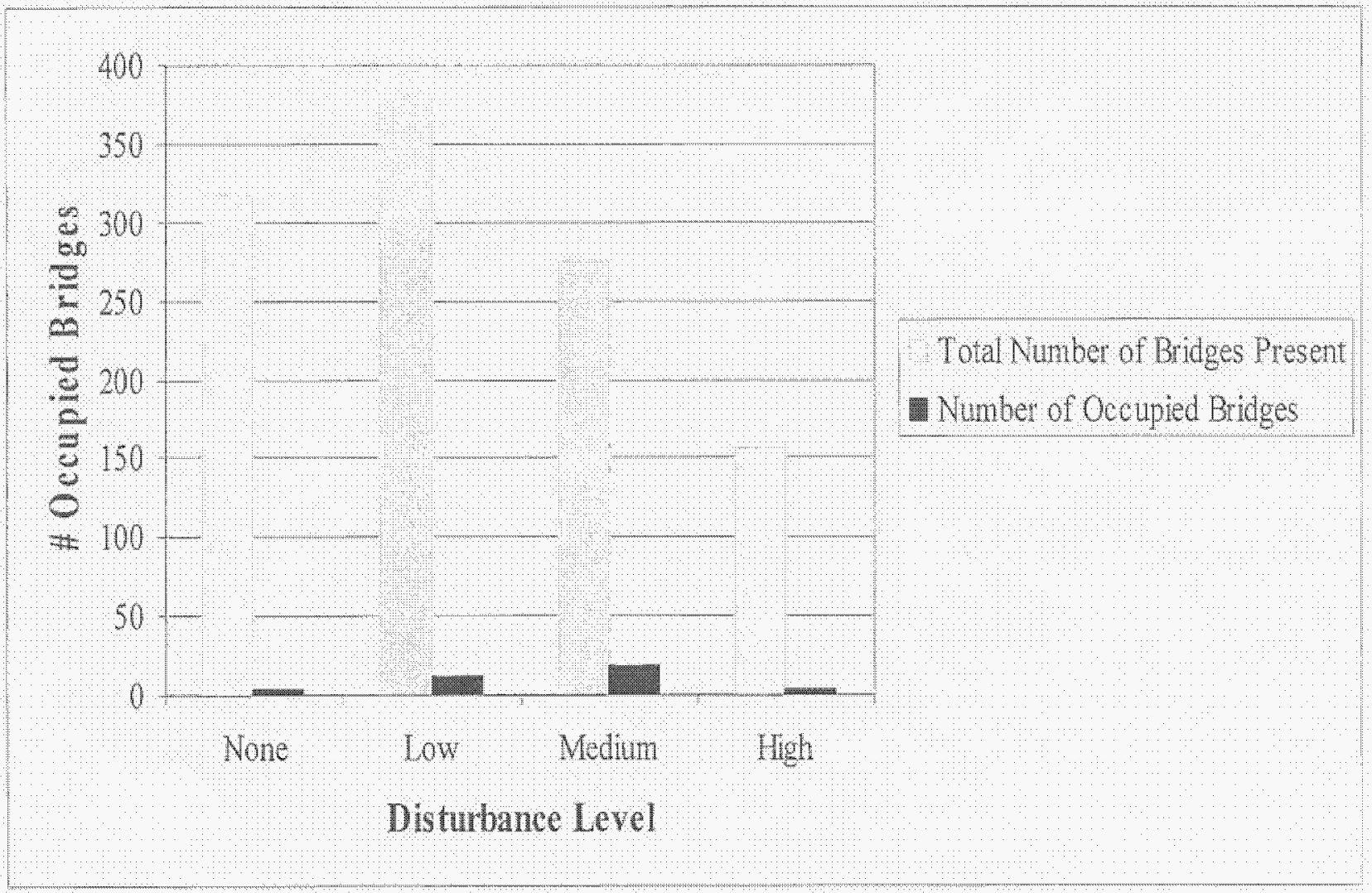

Figure 10. Number of bridges present and occupled by Rafinesque's big-eared bat (Corynorhinus rafinesquii) in South Carolina according to the level of disturbance. Numbers of occupled bridges were: no disturbance $n=3$; low disturbance $n=12$; medium disturbance $\mathrm{n}=18$; and high disturbance $\mathrm{n}=4$. 
Table 4. Types of roosts of Rafinesque's big-eared bats underneath bridges in South Carolina, 2003. The last column refers to the largest number of observed bats in each county from 23 May 2003 to 2 August 2003.

\begin{tabular}{|c|c|c|c|}
\hline Roost Type & County & $\begin{array}{l}\text { No. Bridges } \\
\text { with Bats }\end{array}$ & $\begin{array}{c}\text { No. } \\
\text { Bats/County }\end{array}$ \\
\hline \multirow[t]{16}{*}{ Solitary } & Aiken & 2 & 3 \\
\hline & Allendale & 1 & 1 \\
\hline & Bamberg & 2 & 2 \\
\hline & Barnwell & 1 & 1 \\
\hline & Berkeley & 1 & 1 \\
\hline & Charleston & 1 & 3 \\
\hline & Colleton & 2 & 2 \\
\hline & Dillon & 1 & 1 \\
\hline & Dorchester & 6 & 7 \\
\hline & Hampton & 1 & 1 \\
\hline & Horry & 3 & 4 \\
\hline & Jasper & 4 & 5 \\
\hline & Marion & 7 & 11 \\
\hline & Orangeburg & 9 & 10 \\
\hline & Williamsburg & 6 & 7 \\
\hline & Subtotal & 47 & 59 \\
\hline \multirow[t]{6}{*}{ Adult } & Colleton & 3 & 8 \\
\hline & Dorchester & 1 & 2 \\
\hline & Hampton & 2 & 5 \\
\hline & Orangeburg & 1 & 2 \\
\hline & Williamsburg & 1 & 2 \\
\hline & Subtotal & 8 & 19 \\
\hline \multirow[t]{13}{*}{ Maternal } & Aiken & 1 & 7 \\
\hline & Charleston & 1 & 17 \\
\hline & Colleton & 4 & 67 \\
\hline & Dorchester & 4 & 35 \\
\hline & Georgetown & 1 & 16 \\
\hline & Hampton & 2 & 28 \\
\hline & Horry & 1 & 2 \\
\hline & Jasper & 1 & 14 \\
\hline & Marion & 1 & 31 \\
\hline & Orangeburg & 5 & 76 \\
\hline & Williamsburg & 3 & 49 \\
\hline & Subtotal & 24 & 342 \\
\hline & $T O T A L$ & 79 & 420 \\
\hline
\end{tabular}




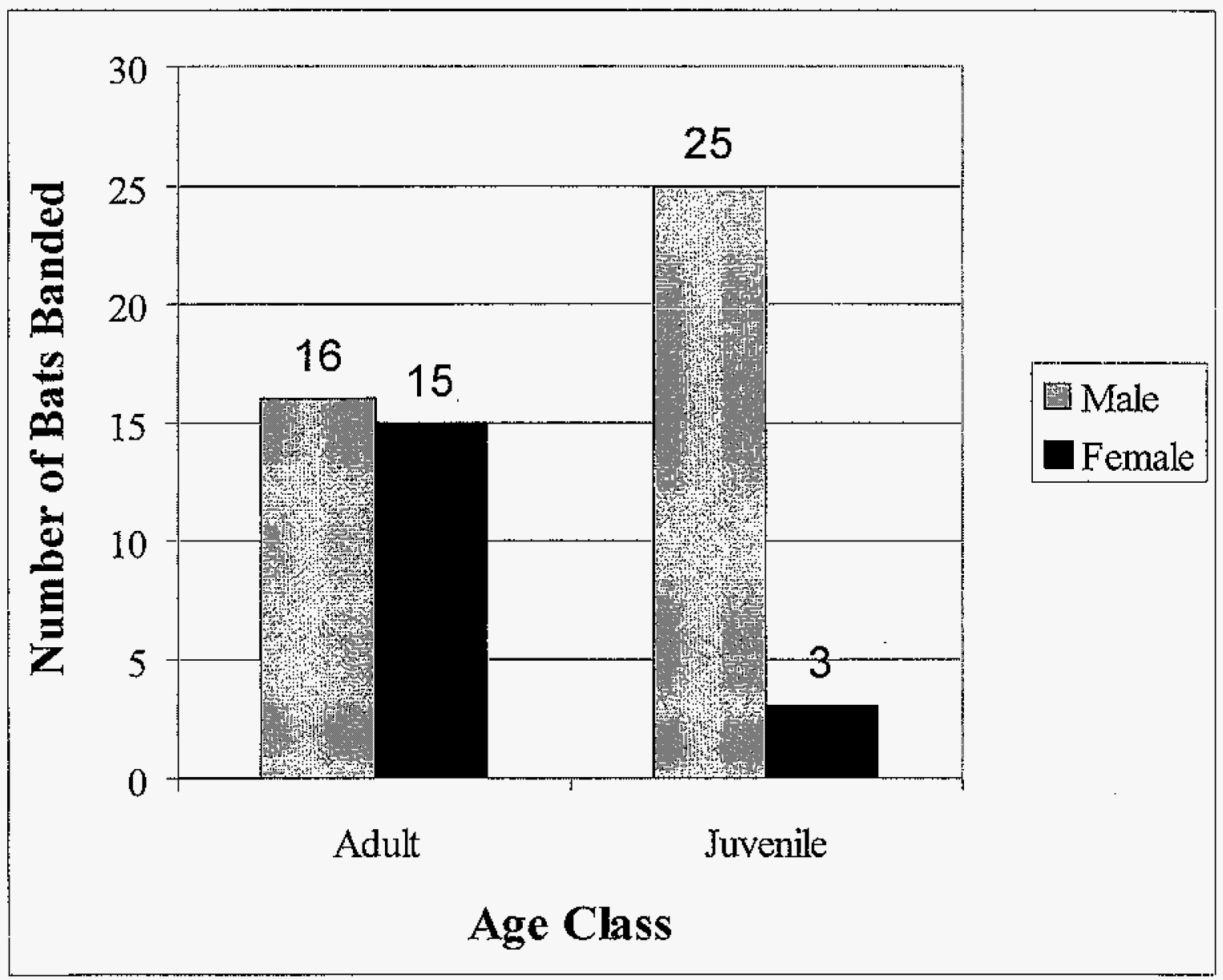

Figure 11. The numbers of Rafinesque's big-eared bats (Corynorhinus rafinesquii) banded in South Carolina, 2003, according to age and sex class. 
Table 5. Concentrations of total $\mathrm{Al}, \mathrm{As}, \mathrm{Cd}, \mathrm{Cr}, \mathrm{Cu}, \mathrm{Hg}, \mathrm{Ni}, \mathrm{Pb}$, and $\mathrm{Se} \mathrm{Zn}$ measured in Rafinesque's big-eared bat from various locations in South Carolina. Values are given as the geometric mean and standard deviations of each sample size.

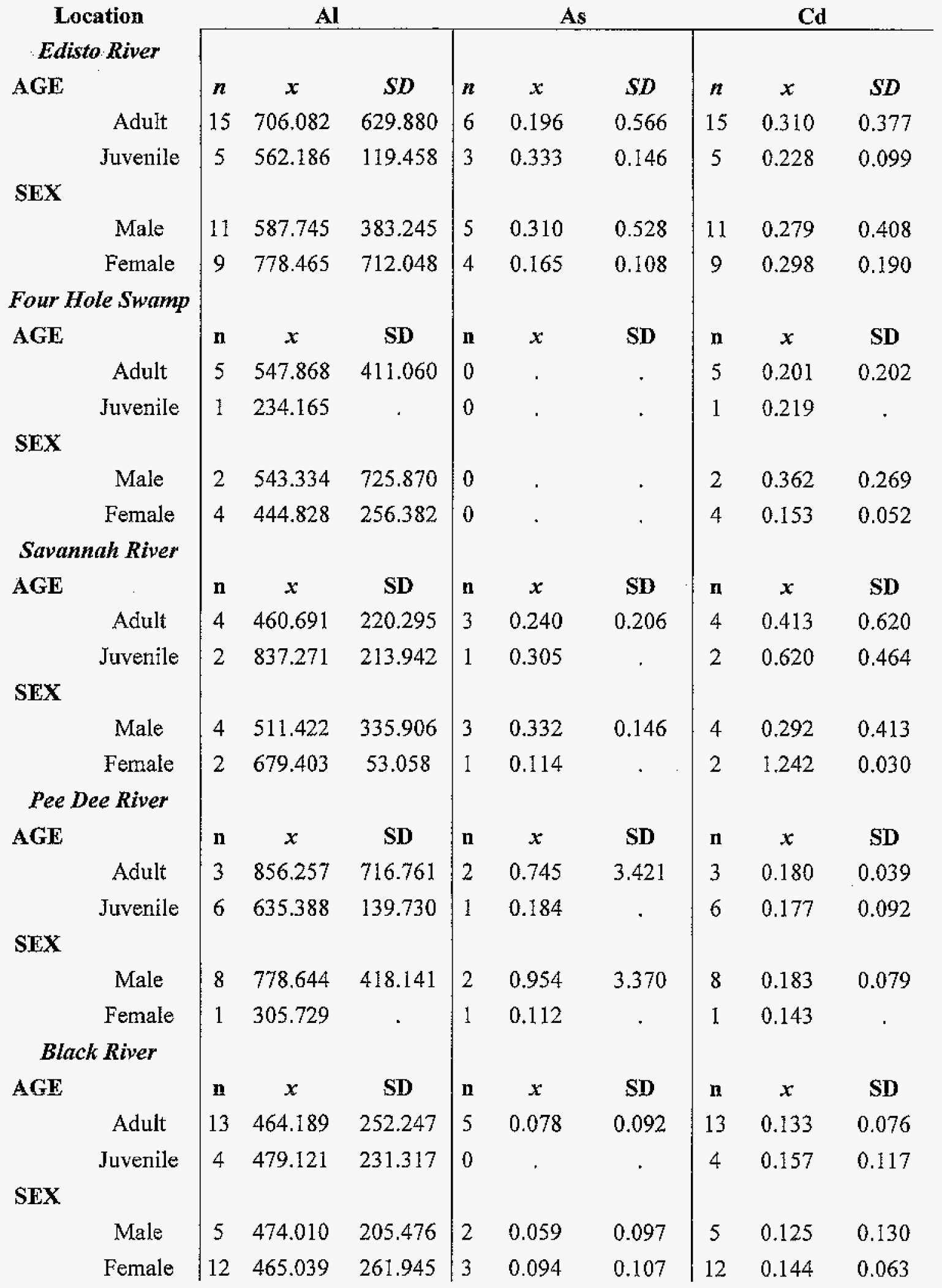


Table 5 continued. Concentrations of total $\mathrm{Al}, \mathrm{As}, \mathrm{Cd}, \mathrm{Cr}, \mathrm{Cu}, \mathrm{Hg}, \mathrm{Ni}, \mathrm{Pb}$, and $\mathrm{Se} \mathrm{Zn}$ measured in Rafinesque's big-eared bat from various locations in South Carolina. Values are given as the geometric mean and standard deviations of each sample size.

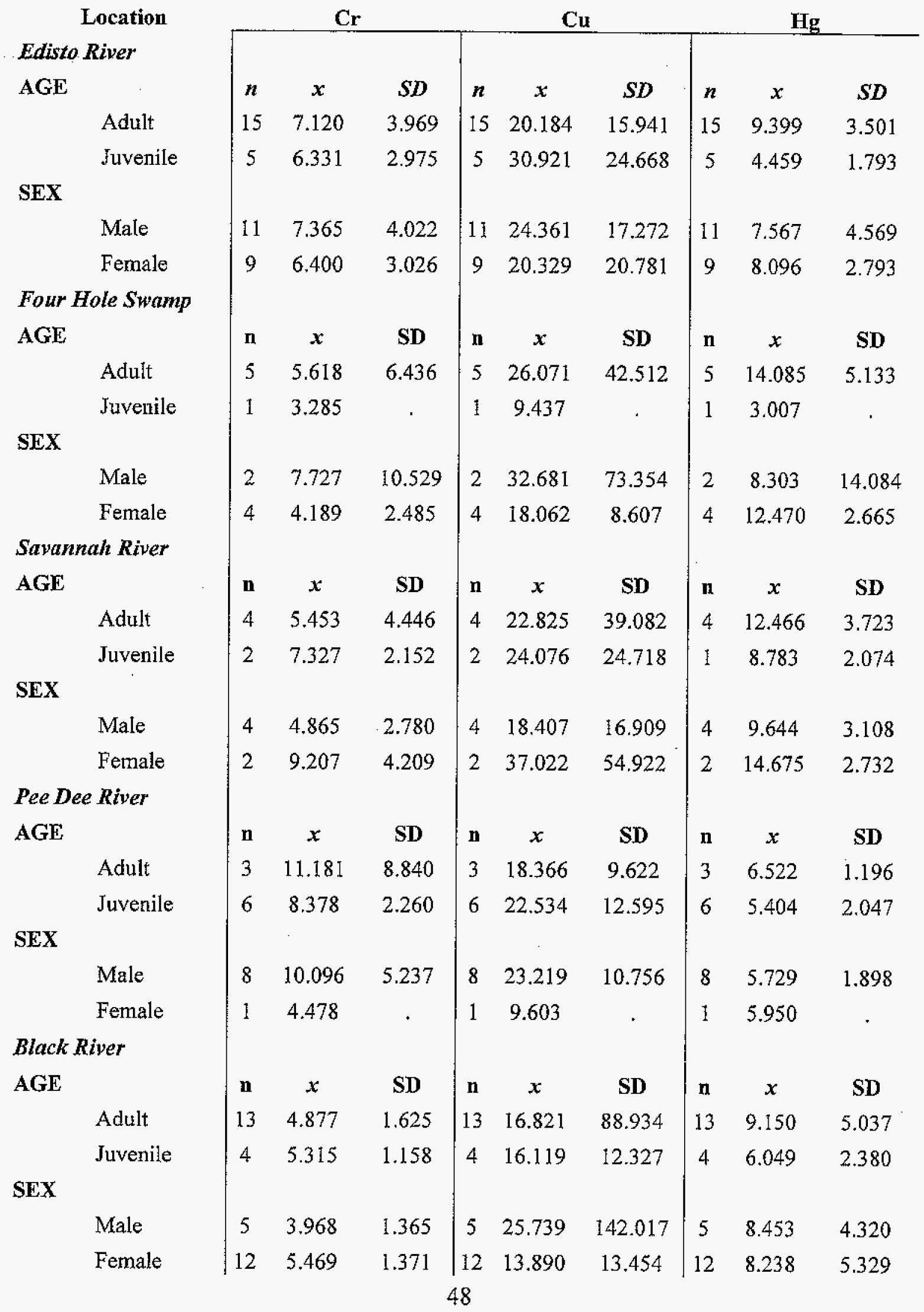


Table 5 continued. Concentrations of total $\mathrm{Al}, \mathrm{As}, \mathrm{Cd}, \mathrm{Cr}, \mathrm{Cu}, \mathrm{Hg}, \mathrm{Ni}, \mathrm{Pb}$, and $\mathrm{Se} \mathrm{Zn}$ measured in Rafinesque's big-eared bat from various locations in South Carolina. Values are given as the geometric mean and standard deviations of each sample size.

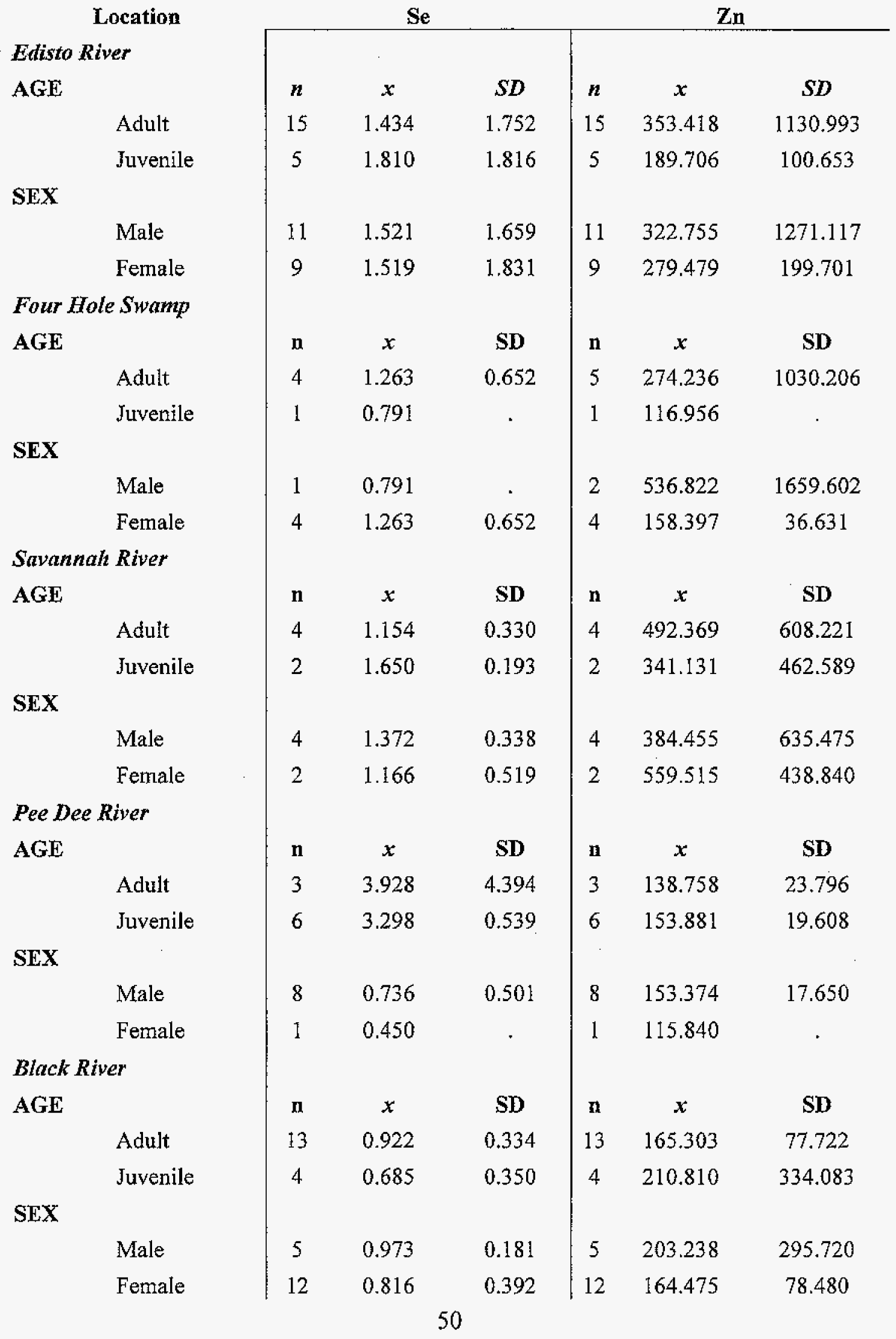


